\title{
Effect of the heterotrophic dinoflagellate Oxyrrhis marina and the copepod Acartia tonsa on vertical carbon flux in and around thin layers of the phytoflagellate Isochrysis galbana
}

\author{
A. B. Bochdansky ${ }^{1, *}$, S. M. Bollens ${ }^{2}$, G. C. Rollwagen-Bollens' ${ }^{2}$, A. H. Gibson ${ }^{2}$ \\ ${ }^{1}$ Ocean, Earth and Atmospheric Sciences, Old Dominion University, Norfolk, Virginia 23529, USA \\ ${ }^{2}$ School of Earth and Environmental Sciences and School of Biological Sciences, Washington State University Vancouver, \\ Vancouver, Washington 98686, USA
}

\begin{abstract}
Dynamics of material and energy flow through food webs differ when resources are allocated in patches in comparison to situations in which the same resources are distributed evenly throughout the water column. Thin layers of plankton are special cases of such resource patches. While previous studies have predominantly focused on the response of organisms to these layers, we investigated how 2 types of grazers in turn affect thin layers. In an experimental study with tightly controlled environmental conditions, we monitored the redistribution of particulate organic (POC), dissolved organic (DOC) and inorganic (DIC) carbon from thin layers of Isochrysis galbana. The 2 grazers (the protist Oxyrrhis marina and the copepod Acartia tonsa) had significant grazing impact on the thin layers despite the fact that their population maxima were observed outside the layers. Both grazers exported carbon from the thin layer as body burden (i.e. incorporated into cell tissue) and through release of DOC and DIC into the environment above and below the layers, albeit at different rates. The copepods released larger amounts of DIC and DOC within the thin layer, while the protist grazer exported more dissolved carbon (DOC and DIC) from the thin layers. In the copepod treatments, a net increase of DIC was observed inside the thin layer (as a result of increased respiration during feeding) and into the atmosphere above the water column due to their vertical migration between the thin layer and the water surface. Whether or not grazers made a positive contribution to DOC net release depended on the strength of grazing, with a negative effect when phytoplanktonitself releasing DOC_-was depleted.
\end{abstract}

KEY WORDS: Patchiness $\cdot$ Thin-layers $\cdot$ Zooplankton feeding $\cdot$ Carbon fluxes

Resale or republication not permitted without written consent of the publisher

\section{INTRODUCTION}

Thin layers of plankton represent common features in coastal and estuarine systems and are usually defined as temporally and spatially coherent layers ranging in thickness from several $\mathrm{cm}$ to $5 \mathrm{~m}$ (Cowles et al. 1998). According to a frequently used definition, their 'signal' in the vertical water column profile (e.g. number of organisms, light attenuation, chlorophyll a) exceeds 3 times the width of the layer at half of the maximum peak (Dekshenieks et al. 2001). Thin layers often, but not always, occur when the water column is stratified within or just below pronounced pycnoclines (Dekshenieks et al. 2001, Alldredge et al. 2002, Bochdansky \& Bollens 2009), and they consist of either phytoplankton or zooplankton at extremely high densities. Only relatively recently has the role of thin layers begun to be understood, primarily due to the implementation of instrumentation that allows for repeated, high-resolution surveys of the water column (Cowles et al. 1998, Dekshenieks et al. 2001, Alldredge et al. 2002). These studies have contributed greatly to 
understanding the mechanisms that are involved in thin layer formation, maintenance and persistence, and illuminated why some organisms may appear cryptic while they are actually confined to thin layers (McManus et al. 2003, 2008, Stacey et al. 2007, Ryan et al. 2008). Thin layers occur in a surprisingly wide range of environments and are documented in the stable embayment of East Sound (Dekshenieks et al. 2001), the coastal ocean influenced by upwelling in Monterey Bay (McManus et al. 2008), and the tidally highly dynamic estuarine system of San Francisco Bay (Bochdansky \& Bollens 2009).

While a large body of research has been directed toward the description of thin layers in the field, in recent years our group has focused on recreating thin layers in $2 \mathrm{~m}$ tall tower tanks and investigating the impact of thin layers on zooplankton and micronekton under highly controlled conditions (e.g. Bochdansky \& Bollens 2004, Clay et al. 2004, Ignoffo et al. 2005). Thin layers can be viewed as one special case of heterogeneity in the water column (other examples being chlorophyll maxima, plankton swarms, and marine snow), which, simply due to their relatively small vertical extent, can be readily reconstructed in the laboratory at scales that are similar to those in the ocean. Moreover, many thin layers in the field are often dominated by one or a few species (Rines et al. 2002), thus making the study of thin layers amenable to laboratory experiments with monocultures.

In our prior laboratory studies, we have sought to understand how thin layers may affect the distribution, behavior, feeding physiology and reproduction of planktonic predators compared to situations in which prey are distributed homogeneously. Using a variety of thin layer organisms, ranging from small phytoplankton to micronekton, we learned that the responses of predators (rotifers, copepods and fish larvae) varied greatly (Bochdansky \& Bollens 2004, Clay et al. 2004, Ignoffo et al. 2005). Some organisms remained in the layers until prey was depleted, while others took short 'excursions' into the layers during their vertical migration while still fully exploiting them for food by feeding in short bursts (Bochdansky \& Bollens 2004, Ignoffo et al. 2005). This differential behavior of zooplankton in thin layers led us to the hypothesis that various zooplankton taxa may affect thin layers in different ways, and that some may contribute more to the export of carbon and mineral nutrients from the layers than others.

Most studies regarding thin layers have aimed to understand the effect of prey heterogeneity on predators. Very little information exists on the reverse, i.e. the effect of the predators on thin layers and their temporal stability. From an ecological point of view, the effect of grazers on thin layers is as important as the effect of thin layers on the consumers. We thus took a different angle from previous studies in that we examined how grazers affect the persistence of thin layers, and how particulate carbon from thin layers is transformed into carbon dioxide and dissolved organic material both within and outside of the layer. The redistribution of carbon within these 3 compartments is important for various physiological processes. Particulate organic matter (POM) is the main source of food for suspension feeders, respired carbon dioxide becomes part of the ocean carbonate system and serves as carbon source for primary producers, and dissolved organic matter is the main source of nutrition for heterotrophic bacteria which then pass this carbon on into the food web via the microbial loop. Net changes in the relative abundance of these 3 pools therefore affect species composition, layer stability and ecological processes within and in the proximity of the layers.

In order to correctly estimate the grazing impact of zooplankton on their prey field (such as thin layer algae), it is valuable to examine processes of consumption and release of dissolved carbon at the same small scales at which thin layers occur (Sutor \& Dagg 2008). Using our tower tank experimental system, we explored the fate of ${ }^{14} \mathrm{C}$-labeled carbon initially bound in a layer of the phytoflagellate Isochrysis galbana and exposed to 2 types of common grazers: one as a representative of the highly diverse group of microzooplankton grazers, the heterotrophic dinoflagellate Oxyrrhis marina, and the other as a representative of the crustacean mesozoplankton, the common estuarine and coastal copepod Acartia tonsa. We used 3 different ratios of grazers to phytoplankton prey in the tanks to establish a gradient in grazing impact. We were thus able to track the removal of particulate organic (POC), and the net release of dissolved inorganic (DIC) and organic (DOC) carbon at unprecedented spatial and temporal resolution.

\section{MATERIALS AND METHODS}

Experimental tower tank system. The tower tank system consisted of four $2 \mathrm{~m}$ tall, rectangular, acrylic glass towers with inner dimensions of $76 \times 50.5 \mathrm{~mm}$ (ca. $8 \mathrm{l}$ each) tapering to a single valve in the lower $10 \mathrm{~cm}$ of the tanks (Fig. 1). The tanks resided in a temperature-controlled room with white light sources above each tank. They were shielded from stray light from each other's light source by means of black curtains. Walls were painted black to minimize reflections. Each tank had 10 ball valves on one side and 1 valve on the bottom (Fig. 1). At the location of the thin layers, in the center of the tank, 5 valves were spaced at $1 / 2$ the distance of the valves outside the layer 


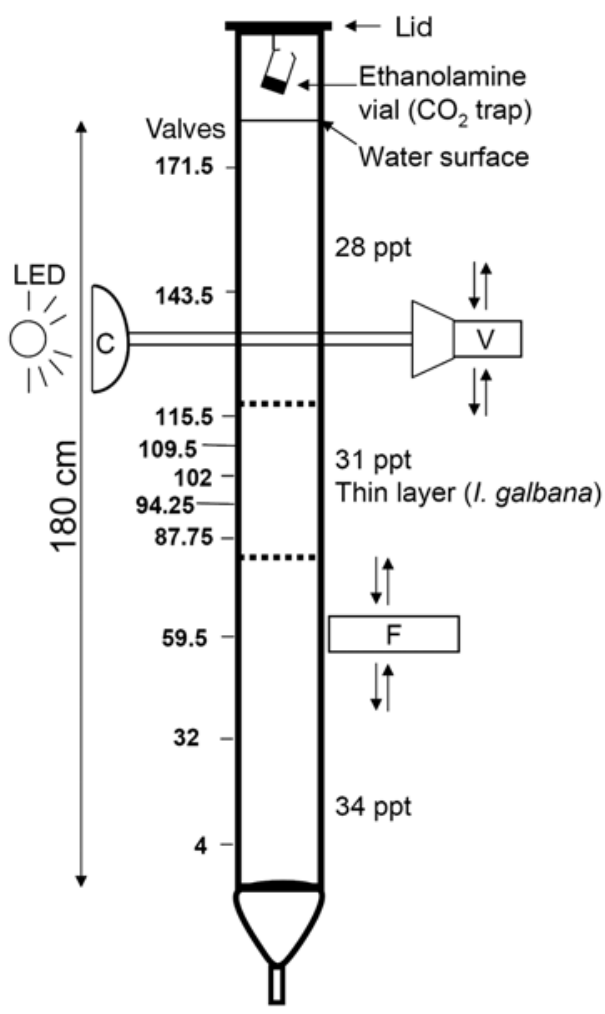

Fig. 1. Tower tank used in the experiments. Valves were distributed at a higher density at the thin layer to facilitate high-resolution sampling. Numbers next to the valves = water column heights at each valve $(\mathrm{cm})$. A panning video camera (V) with an infrared LED and a collimating lens (C) was used to track the distribution of copepods. An in situ fluorometer (F) allowed for non-invasive detection of chlorophyll through the tank walls. Arrows = directions of movements of both instruments

to obtain higher spatial resolution in sampling the thin layer (Fig. 1). Two valves were located well above, and 3 well below the thin layer. Each tank was equipped with a camera cradle with an infrared diode and a collimating lens on one side, and a black and white video camera sensitive to infrared light on the other side (Fig. 1). This system produced shadow images of Acartia tonsa that remained in focus over the entire cross section of the tanks. Most crustaceans are blind to red and infrared light, therefore their behavior was not influenced by the camera light. In hourly intervals, vertical pans (6 min duration over the entire length of the tank) captured the distribution of individuals of $A$. tonsa during light and dark cycles, and were later analyzed manually from VHS video tapes. The light intensity was 4.1 and $0.6 \mu \mathrm{mol} \mathrm{m} \mathrm{m}^{-2} \mathrm{~s}^{-1}$ at the surface and the bottom, respectively, and was the same for all tanks. This light is strong enough to provide cues for vertical migration but is less than required for net photosynthesis of Isochrysis galbana (Dubinsky et al. 1986).
Culture. Isochrysis galbana (strain CCMP 462) was obtained from the Provasoli-Guillard National Center for Culture of Marine Phytoplankton (Bigelow Laboratory for Ocean Sciences, Maine). Oxyrrhis marina (strain SPMC 107) was donated by Suzanne Strom of the Shannon Point Marine Center (Anacortes, Washington). Acartia tonsa was purchased from the culture collection of the Marine Biological Laboratory at the University of Copenhagen.

Artificial seawater (Instant Ocean, Spectrum Brands) was used for both culture and in the experimental tanks. It was set up at least 1 day before use, vigorously aerated overnight to dissolve all salts and to adjust the $\mathrm{pH}$, and finally gravity-filtered through a $1 \mu \mathrm{m}$ cartridge filter. Isochrysis galbana was grown in $\mathrm{f} / 2$ medium without silica (Guillard 1983) in 31 ppt artificial seawater at room temperature, under a 12:12 h light:dark cycle. During the experimental period, Oxyrrhis marina culture was fed daily with I. galbana. Acartia tonsa was kept in 201 buckets in the dark at room temperature with light aeration and fed daily with a mixture of Rhodomonas salina and I. galbana cultures. A. tonsa can be grown on $R$. salina alone, but the addition of the smaller sized $I$. galbana helped in naupliar development and acclimated copepods to the organism used in the thin layer experiments. In contrast to $R$. salina, which rapidly settles out of the water column, I. galbana is a very suitable organism for establishing thin layers in experimental tanks because this small alga remains suspended over extended periods of time.

The use of Isochrysis galbana was a deliberate choice as the thin layer organism as both Oxyrrhis marina and Acartia tonsa feed well on this small alga (Tang \& Taal 2005). Details on the functional responses of O. marina and A. tonsa in bottle experiments on a variety of algae, including I. galbana, can be found in Kiørboe (1989), Hansen et al. (1996), and Tang \& Taal (2005). Grazer densities were selected to create a gradient in grazing impact for each experiment, whereby the A. tonsa grazing pressure fell between the $2 O$. marina treatments. Establishing a gradient where grazing of the protist plankton bracketed the copepod grazing pressure was important because we were mostly interested in the effect of grazer type and, thus, needed to experimentally control for relative grazing impact. The tower tanks in this study allowed enough spatial range for the grazers to find their preferred position in relation to the food layer, which is different from traditional bottle incubations where predators and prey were forced to reside within the same parcel of water.

Thin layer experiments. ${ }^{14} \mathrm{C}$ was chosen as the tracer because of the wide dynamic range that a radioisotope affords. We can reliably measure values as little as 
$50 \mathrm{dpm}$ (i.e. when counting each vial for $20 \mathrm{~min}$ ) and as high as $2000000 \mathrm{dpm}$ on a linear scale. This isotope technique does not allow us to calculate absolute values of carbon transfer due to inherent problems with the recycling of carbon among various pools and isotope dilution (e.g. Conover \& Francis 1973). However, this method provides relative fluxes at high spatial resolution and highest sensitivity. Re-uptake of ${ }^{14} \mathrm{C}$ by the algae was minimized by the low light intensities. In each of five $48 \mathrm{~h}$ experiments, 4 tower tanks were used simultaneously; 1 tank served as a control (thin layer of Isochrysis galbana alone), 1 as the Acartia treatment (I. galbana +300 Acartia tonsa), and 2 as Oxyrrhis treatments (I. galbana +4 million cells of Oxyrrhis marina [high treatment], and I. galbana +800000 cells of $O$. marina [low treatment]; all grazer numbers are given for the entire tank volume). In a 11 Pyrex glass bottle, $750 \mathrm{ml}$ of an exponentially growing I. galbana culture was inoculated with $100 \mu \mathrm{Ci} \mathrm{l}^{-1}$ of $\mathrm{NaH}^{14} \mathrm{CO}_{3}$ (final concentration), mixed and then tightly capped. The culture was allowed to incorporate ${ }^{14} \mathrm{C}$ for at least $5 \mathrm{~d}$ before each experiment to ensure uniform labeling of the cells (Nielsen \& Olsen 1989, Bochdansky et al. 1999). Cells were grown in continuous light, and not stirred. On the morning of each experiment, $500 \mathrm{ml}$ of the suspended cells were decanted into a separate jar. This procedure avoided the inclusion of older sinking cells collecting in the bottom of the jar. The cells were washed with a Vivaflow 200 (Vivascience Ltd) tangential flow filtration device connected to a Masterflex peristaltic pump with a flow rate of $\sim 60 \mathrm{ml}$ per min. The culture was repeatedly diluted to $4 \mathrm{l}$ and then reduced in volume to $250 \mathrm{ml}$. In this fashion I. galbana cells could be gently separated from the unincorporated label with a total dilution of the label of $\sim 512$-fold. The culture was subsequently divided into 4 equal portions, one for each tank. Two of those were diluted to $1 \mathrm{l}$ with $31 \mathrm{ppt}$ artificial seawater (for the control and Acartia treatment), and 2 were amended with $O$. marina at 800 and 4000 cells $\mathrm{ml}^{-1}$, respectively. We counted the amount of $I$. galbana introduced with $O$. marina by this procedure and determined that it was negligible if we did not add any $I$. galbana to the $O$. marina cultures for $24 \mathrm{~h}$ before the experiments.

The tanks were filled with artificial seawater at 3 different salinities to create a layered water column. The bottom of all tanks, up to valve 7 ( 85 $\mathrm{cm}$ above the bottom of the tank), received 34 ppt artificial seawater introduced through valve 5. The tanks were then filled gently and simultaneously with the thin layer mixtures (2 tanks with Isochrysis galbana, 2 tanks with $I$. galbana + Oxyrrhis marina) using a 4 channel peristaltic pump (Minipuls 3, Gilson) and equal lengths of silicone tubing extended over the lip of each tank. Care was taken to avoid mixing by hav- ing the water run slowly down the inside of the tank walls. When the water level reached just below valve 5 ( $87 \mathrm{~cm}$ above the bottom of the tank), the flow was stopped in all tanks. Through the completely opened valve \#5, 300 Acartia tonsa mature females in $50 \mathrm{ml}$ of 31 ppt artificial seawater were added to the Acartia treatment tank. The other 3 tanks received the same volume of artificial seawater without copepods to keep the dilution and disturbance levels identical in all tanks. Then, the remainder of the thin layer mixtures was added up to valve $3(\sim 115 \mathrm{~cm}$ above the bottom of the tank). Finally, 28 ppt artificial seawater was added on top of each thin layer, again by using the peristaltic pump, and filled to $5 \mathrm{~cm}$ above valve 1, creating a $180 \mathrm{~cm}$ high water column. This filling procedure resulted in a central pycnocline and a welldefined and persistent thin layer in each of the 4 tanks. The top of each tank was capped with a lid which had a $20 \mathrm{ml}$ glass scintillation vial hanging from a hook. The vial was filled with $5 \mathrm{ml}$ of ethanolamine, which is an efficient trap for $\mathrm{CO}_{2}$ gas (Kupparinen \& Uusi-Rauva 1980, Abbott et al. 1992). In total, 5 sets of tank experiments were performed over the course of $1.5 \mathrm{mo}$. Each experiment was initiated at 21:00 $h$, just before the lights were switched off in a 12:12 h light:dark cycle.

Water samples from each valve on each tank (including 2 bottom valves) were taken initially, and then every $12 \mathrm{~h}$ (just after the lights came on at 09:00 $\mathrm{h}$ and just before the lights went out at 21:00 h) over a $48 \mathrm{~h}$ period. The valves were purged by discarding the first $5 \mathrm{ml}$ discharge, then another $10 \mathrm{ml}$ was taken for further processing as described below (Fig. 2). In 2 experiments, the sampling was continued for another night to obtain a final sample from the ethanolamine vial after $60 \mathrm{~h}$.

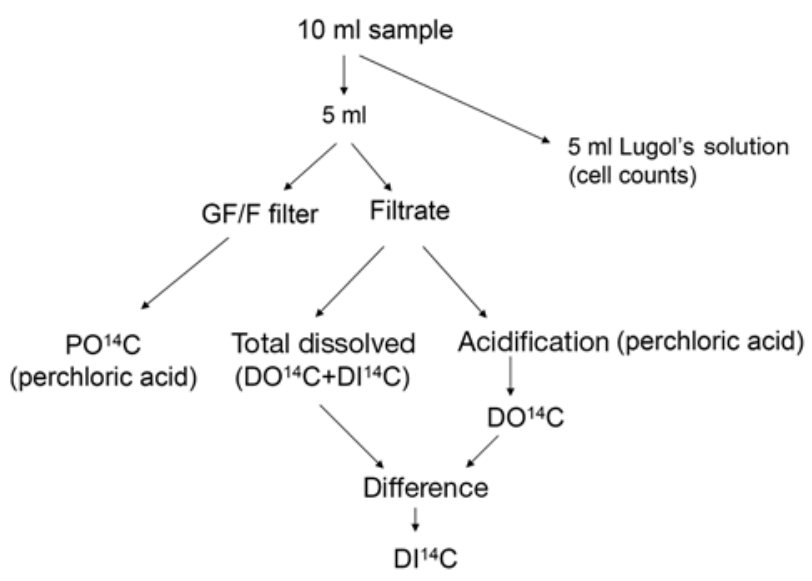

Fig. 2. Sample processing to obtain cell counts and 3 different carbon fractions. Particulate organic (POC), dissolved organic (DOC) and dissolved inorganic (DIC) carbon 
Fluorometry. In $12 \mathrm{~h}$ intervals, a DFL in situ fluorometer (WET-labs) was used to non-invasively determine the distribution of Isochrysis galbana through the tank in $\sim 10 \mathrm{~cm}$ distances (coinciding with valve positions and mid-way between valves). For calibration of the instrument, subsamples for chlorophyll a (chl a) analysis ( 0.25 to $5 \mathrm{ml}$, depending on concentration) were filtered onto GF/F filters, extracted in $5 \mathrm{ml} 90 \%$ HPLCgrade acetone, and measured on a Turner Model 10AU fluorometer (Strickland \& Parsons 1972).

Sample processing. The valve samples were processed to obtain cell counts (Isochrysis galbana and Oxyrrhis marina) and radioactive values for 3 carbon fractions: particulate organic carbon $\left(\mathrm{PO}^{14} \mathrm{C}\right)$, dissolved organic carbon $\left(\mathrm{DO}^{14} \mathrm{C}\right)$ and dissolved inorganic carbon (DI ${ }^{14} \mathrm{C}$ ) (Fig. 2). First, $5 \mathrm{ml}$ of each valve sample was filtered over a $\mathrm{GF} / \mathrm{F}$ filter. In order to determine the total dissolved fraction $\left(\mathrm{DO}^{14} \mathrm{C}+\mathrm{DI}^{14} \mathrm{C}\right), 0.5 \mathrm{ml}$ of the filtrate was transferred to a pony vial and $4 \mathrm{ml}$ of biodegradable Ecolume scintillation cocktail was added immediately. For the $\mathrm{DO}^{14} \mathrm{C}$ fraction, another $0.5 \mathrm{ml}$ of the filtrate was placed in a pony vial and $250 \mu \mathrm{l}$ of $0.2 \mathrm{~N}$ perchloric acid was added to drive off $\mathrm{DI}^{14} \mathrm{C}$ in a fume hood for at least $10 \mathrm{~h}$. Preliminary experiments showed that it took at least $10 \mathrm{~h}$ to remove $>95 \%$ of the inorganic fraction. $\mathrm{DI}^{14} \mathrm{C}$ was determined by subtracting the $\mathrm{DO}^{14} \mathrm{C}$ values from the $\mathrm{DO}^{14} \mathrm{C}+$ $\mathrm{DI}^{14} \mathrm{C}$ values (Fig. 2). To measure $\mathrm{PO}^{14} \mathrm{C}$, the GF/F filters were acidified and incubated for $>10 \mathrm{~h}$ inside the pony vials to remove any residual label, and $4 \mathrm{ml}$ of scintillation cocktail was then added. Radioactivity $(\mathrm{dpm})$ in all samples was measured on a Packard TriCarb liquid scintillation counter (model 2100TR) using quench correction and a counting time to reach a 2sigma of $0.5 \%$, or a maximum of $20 \mathrm{~min}$ (whichever came first) per vial. The remaining $5 \mathrm{ml}$ of the initial sample were transferred into a glass vial and 3 drops of Lugol's solution were added (Fig. 2). Aliquots of these samples (adjusted for approximate cell densities) were later settled overnight in plastic well plates for enumeration of Isochrysis and Oxyrrhis using an inverted microscope at $200 \times$. In Expt 5 only, an additional $5 \mathrm{ml}$ were taken from tank valves $2,3,5,7$ and 10 and preserved in $2 \% \quad 0.2 \mu \mathrm{m}$ filtered formaldehyde for bacterial counts under an epifluorescence microscope using DAPI stain (Porter \& Feig 1980).

Calculation of loss rates in thin layers. To obtain loss coefficients $(g)$ for each thin layer valve, the negative exponential model shown in Eq. (1) was fitted using Gauss-Newton approximation (SAS statistical software). This loss coefficient is equivalent to the grazing coefficient $g$ in Frost (1972). Inclusion of a time series instead of simple endpoint measurements is desirable as it mitigates the influence of sampling and analytical errors.

$$
C_{t}=C_{0} \times \mathrm{e}^{(-g \times t)}
$$

$C_{t}$ is the concentration at time $t, C_{0}$ the concentration at the start of the experiment (for either chl $a$ or $\mathrm{PO}^{14} \mathrm{C}$ ), $g$ is the loss coefficient $\left(\mathrm{h}^{-1}\right)$, and $t$ is elapsed time (h).

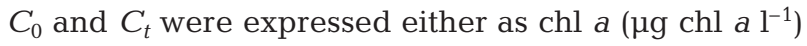
or as $\mathrm{PO}^{14} \mathrm{C}\left(\mathrm{dpm} \mathrm{ml}^{-1}\right)$. In addition, loss coefficients were determined for each thin layer valve in the Isochrysis galbana controls (termed $k$ ), and then subtracted from the grazer treatment in order to arrive at net losses due to grazer activity $(g-k)$.

\section{RESULTS}

\section{Phytoplankton vertical distributions}

We determined the efficacy and dynamic range of the in situ fluorometer for measuring chlorophyll distributions non-invasively through the tank walls (Fig. 3). The values measured in our experiments were always $<600$ RFU, which fell well within the dynamic range of the instrument's capacity to discern differences in chl a concentration (Fig. 3). The equation of the fit sigmoid curve is:

$$
C=\frac{C_{\max }}{1+\mathrm{e}^{-\left(x-x_{0}\right) / a}}
$$

where $C$ is chl a $\left(\mu \mathrm{g} \mathrm{l}^{-1}\right), C_{\max }$ the asymptote, $x_{0}$ the $x$ coordinate of the inflection point, and $a$ is a shape parameter. Values were $C_{\max }=37.6, a=78.7, x_{0}=$ 500.33. A distinct Isochrysis galbana thin layer remained in the control tanks (algae only) over $48 \mathrm{~h}$, although cell numbers decreased significantly as measured in chl $a$ and $\mathrm{PO}^{14} \mathrm{C}$ (Fig. 4).

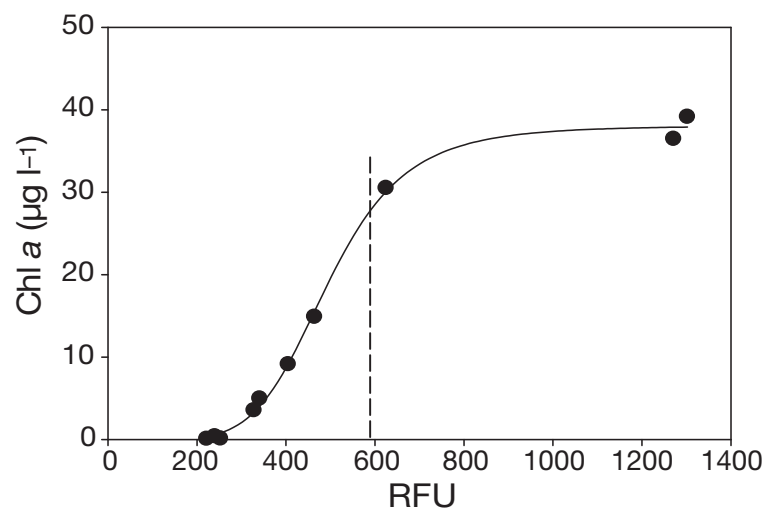

Fig. 3. Relationship between measured relative fluorescence (RFU) using a non-invasive fluorometer held against the tank wall, and amount of chl a determined from samples of Isochrysis galbana taken through valves in the tower tanks, extracted in $90 \%$ acetone and measured in a Turner fluorometer. During the experiments, concentrations of I. galbana were kept below the dashed line and within the dynamic range of this method 

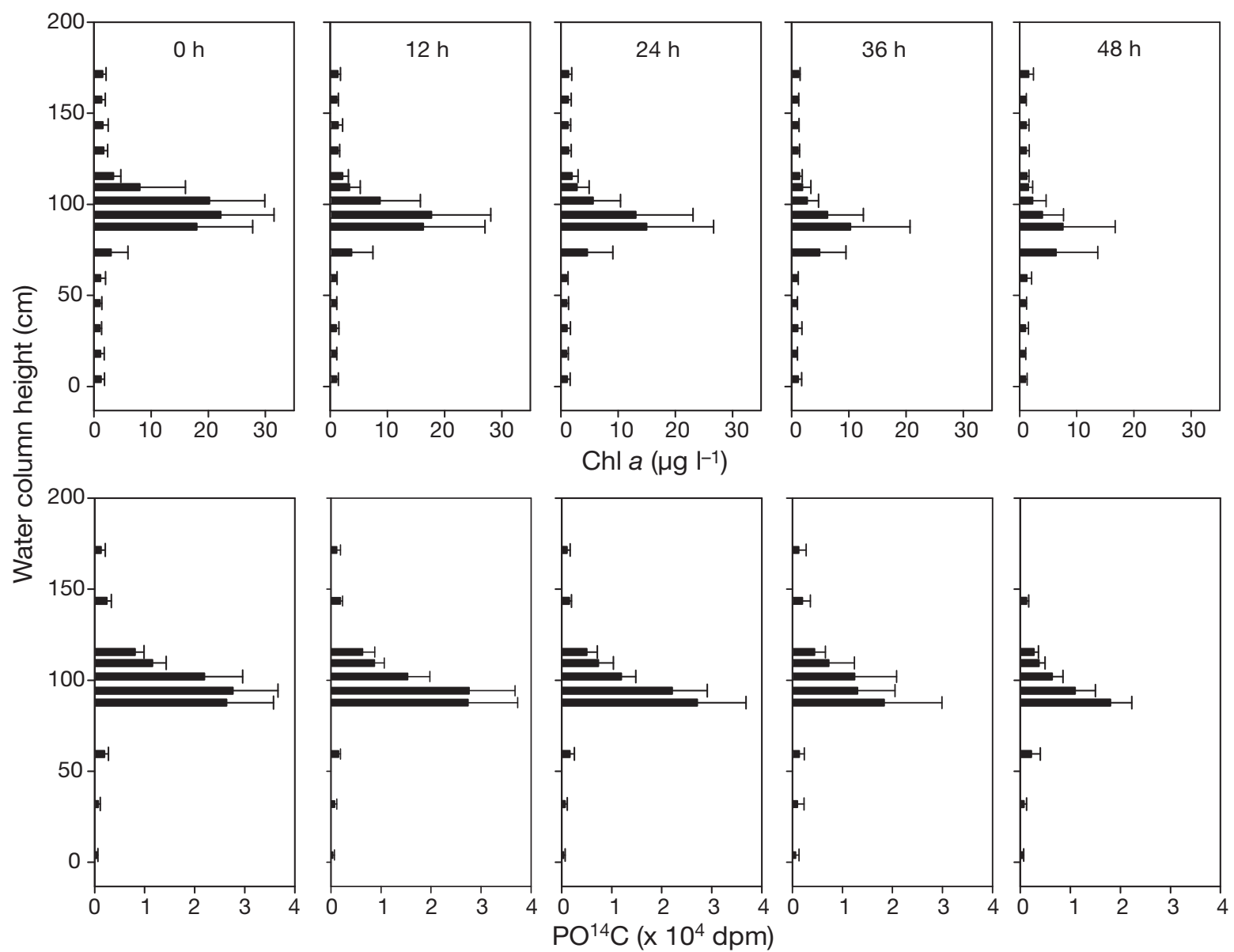

Fig. 4. Development of chl a (upper row) and particulate organic C ( $\mathrm{PO}^{14} \mathrm{C}$ ) (lower row) in control treatments (without grazers) over $48 \mathrm{~h}$ in 5 independent experiments. $\mathrm{PO}^{14} \mathrm{C}$ values were subsequently subtracted from all grazer treatments to result in net redistribution of $\mathrm{PO}^{14} \mathrm{C}$ (see Fig. 7)

\section{Grazer vertical distributions}

Oxyrrhis marina and Acartia tonsa were added to the tanks directly within the thin layer, and remained in the layer for several hours (Figs. 5 \& 6). Over time, both grazers moved out of the layer. However, they migrated in different ways: O. marina spread out from the layer in both directions, although primarily resided in the lower half of the tank throughout the experiments (Fig. 5). The A. tonsa population slowly moved away from the thin layer towards the upper part of the water column during the first $24 \mathrm{~h}$, and then remained there relatively evenly distributed (Fig. 6). Diel vertical migration based on differential distributional patterns was not observed, although individuals still moved about in the tanks. Cell counts and video analyses are snapshots of the population distribution and are not indicative of the migration of individual organisms. Bacterial numbers increased significantly over $48 \mathrm{~h}$ in all treatments (Table 1). In pairwise comparisons of bacterial numbers, only the high Oxyrrhis treatment was significantly different from the other treatments (n $=38, \mathrm{p}<0.05$, Tukey test for multiple pairwise comparisons) (Table 1).

\section{Grazing impact}

In the grazer treatments, the thin layers were steadily reduced over $48 \mathrm{~h}$ and almost depleted in the

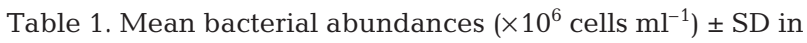
Expt 5 in all 4 treatments. Numbers increased significantly over $48 \mathrm{~h}$ (n $=38, F=25.46, \mathrm{p}<0.0001)$. Only the high Oxyrrhis marina treatment $\left({ }^{*}\right)$ was significantly different from the others in a Tukey pairwise comparison test between treatments $(\mathrm{n}=38, \mathrm{p}<0.05)$. I.: Isochrysis, A.: Acartia

\begin{tabular}{|lcccc|}
\hline Time & I. galbana & $\begin{array}{c}\text { O. marina } \\
\text { low }\end{array}$ & A. tonsa & $\begin{array}{c}\text { O. marina } \\
\text { high }\end{array}$ \\
\hline $0 \mathrm{~h}$ & $1.24 \pm 0.23$ & $1.33 \pm 0.38$ & $1.08 \pm 0.22$ & $1.85 \pm 0.54^{*}$ \\
$48 \mathrm{~h}$ & $1.71 \pm 0.43$ & $2.21 \pm 0.51$ & $2.01 \pm 0.65$ & $2.96 \pm 0.78^{*}$ \\
\hline
\end{tabular}




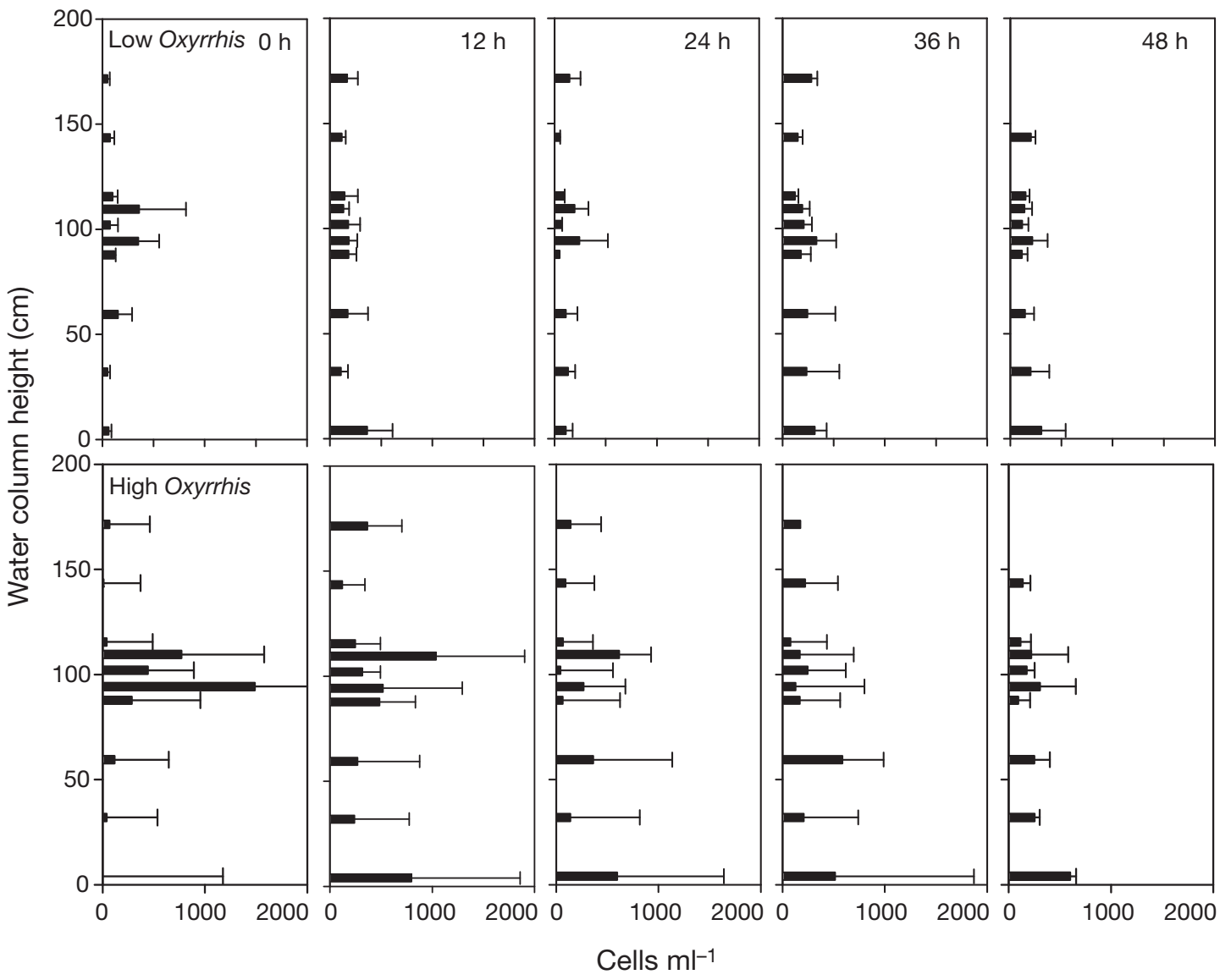

Fig. 5. Oxyrrhis marina. Distribution (48 h) of O. marina in the low (upper row) and high (lower row) treatments. O. marina was initially added to the layer but moved primarily to the bottom half of the tank. Population responses, however, do not represent movements of individual cells

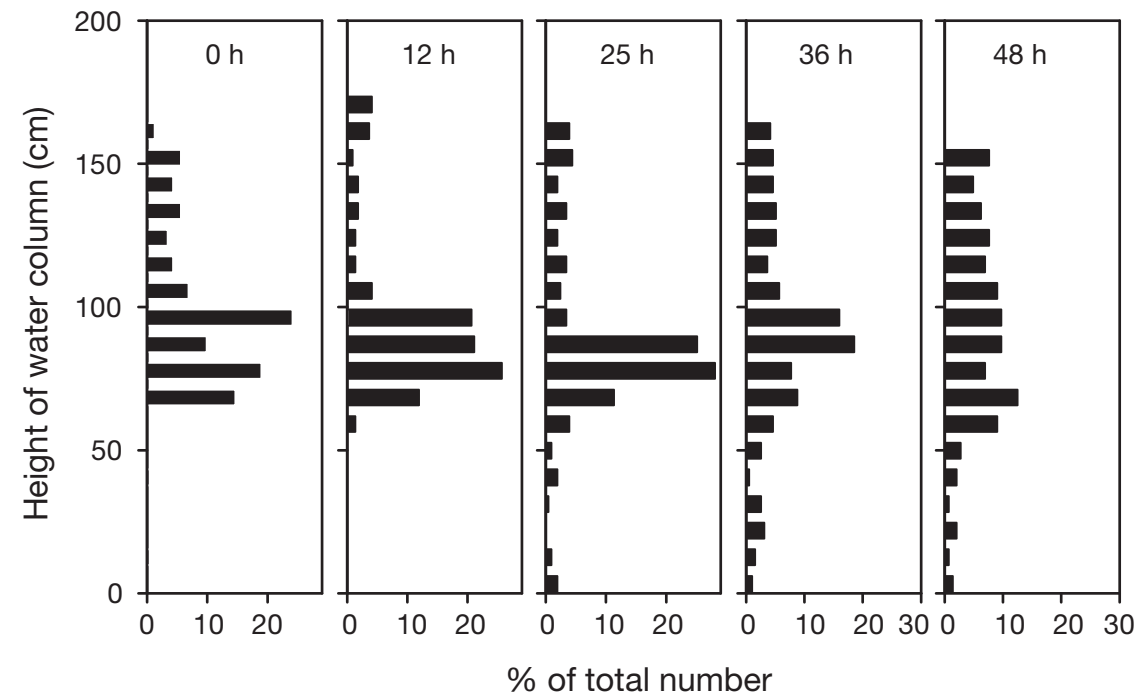

Fig. 6. Acartia tonsa. Migration of A. tonsa during one representative experiment. It slowly moved out of the layer (where it was added) and remained primarily within the upper part of the tank. No diel vertical migration was observed, although individuals may have moved repeatedly into and out of the layer 


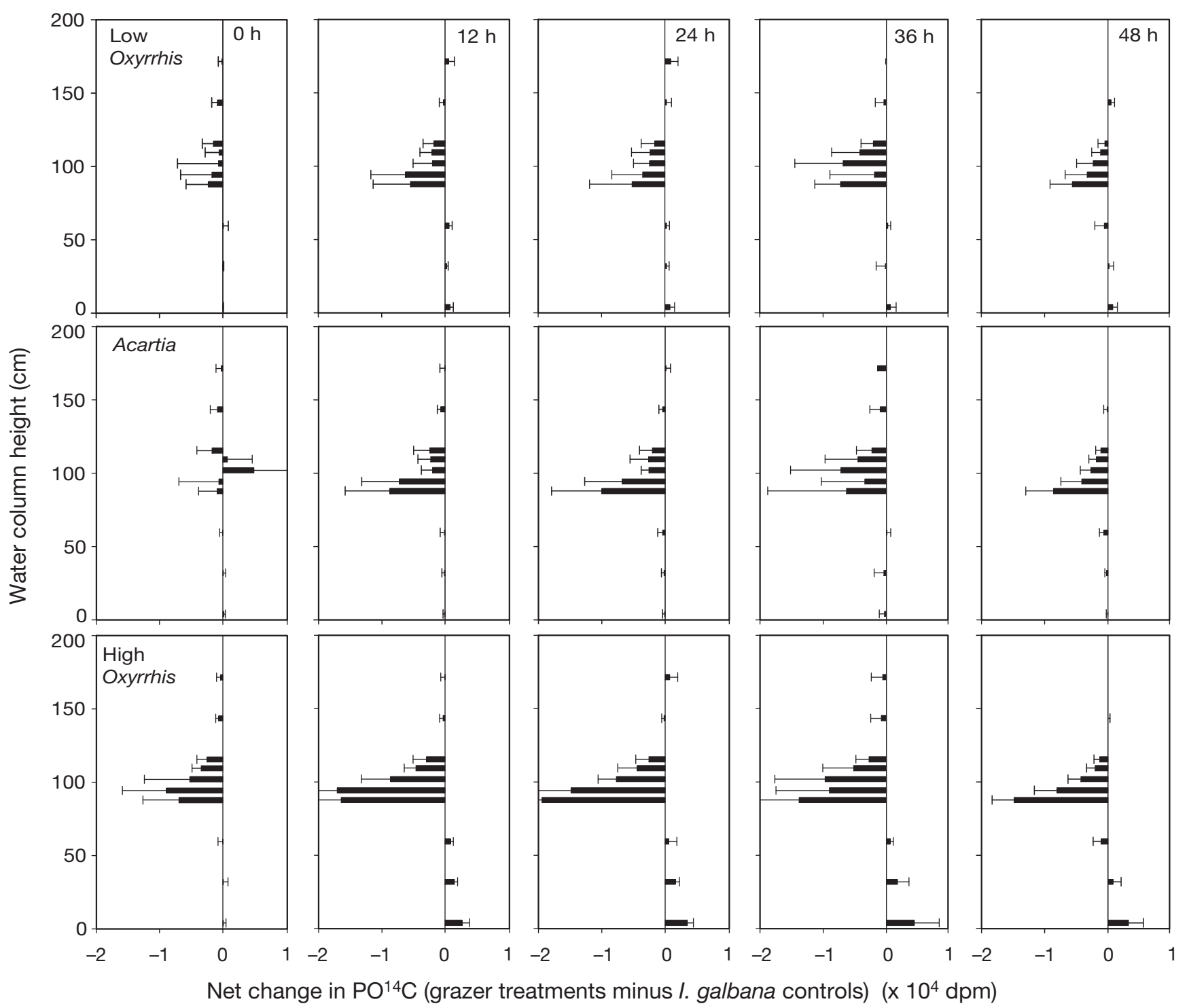

Fig. 7. Oxyrrhis marina and Acartia tonsa. Net particulate organic $\mathrm{C}\left(\mathrm{PO}^{14} \mathrm{C}\right)$ distribution in the 3 grazer treatments (low and high O. marina, A. tonsa) over $48 \mathrm{~h}$ in $12 \mathrm{~h}$ intervals. $\mathrm{PO}^{14} \mathrm{C}$ in the Isochrysis galbana controls were subtracted to show net effect of the grazers. Values = averages over 5 experiments for specific valve locations; error bars $=\mathrm{SD}$. The 5 closely spaced valves in the center of the tank represent the location of the thin layers

highest grazing treatment with Oxyrrhis marina. By subtracting the $\mathrm{PO}^{14} \mathrm{C}$ values of the controls (Isochrysis galbana without grazers), we arrived at netchanges of $\mathrm{PO}^{14} \mathrm{C}$ in the tanks over time for the 3 grazer treatments (Fig. 7). A negative sign indicates that there was less label in the grazer treatment than in the matching I. galbana control. The slight increase of $\mathrm{PO}^{14} \mathrm{C}$ in the lower part of the tank in the O. marina treatments was primarily due to the increased radioactivity of $O$. marina cells which left the thin layers. In a tower tank setting, such as in this experiment, where predators are not forced to be at the same location as their prey, per predator clearance or ingestion rates cannot easily be calculated. It is more useful to calculate the loss rates from the perspective of the prey (i.e. the thin layer). In order to explore the observed losses of $\mathrm{PO}^{14} \mathrm{C}$ in the thin layers at high resolution (5 valves within the $30 \mathrm{~cm}$ of the thin layer), the decrease of chl $\mathrm{a}$ and $\mathrm{PO}^{14} \mathrm{C}$ over time was used to calculate loss rate coefficients over time (Eq. 1). An example for the non-linear curve fitting procedure is provided for the central thin layer valve in Fig. 8. Corrected for the decreases in the I. galbana controls $(k)$, loss coefficients at the 5 thin layer valves based on either chl a or $\mathrm{PO}^{14} \mathrm{C}$ showed that Acartia tonsa had a relatively larger impact at the top portion of the lay- 


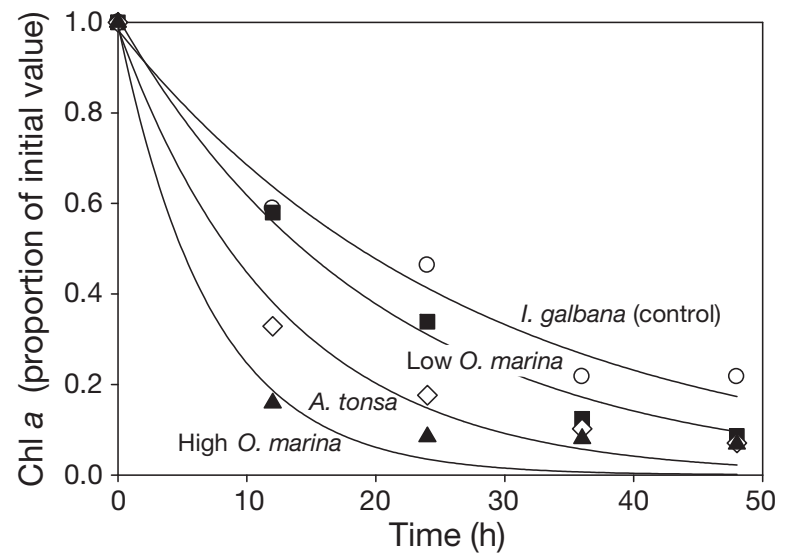

Fig. 8. Isochrysis galbana, Oxyrrhis marina and Acartia tonsa. Example of the fitting of the exponential decay function (Eq. 1, analogous to the Frost 1972 equation) to determine loss coefficient, $g\left(\mathrm{~h}^{-1}\right)$, for each of the grazer treatments. Curves were fit to the raw data; however, for better clarity, only the means of 5 independent experiments are shown. (O) I. gal-

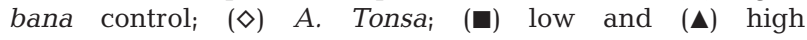
concentration $O$. marina

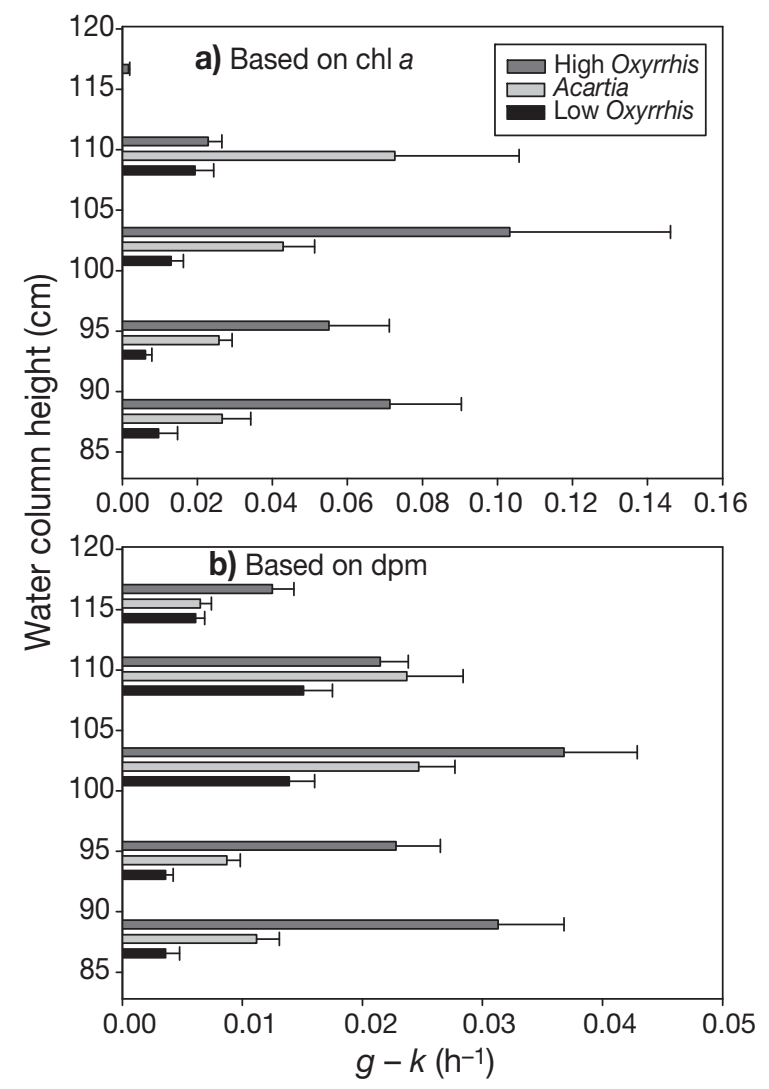

Fig. 9. Oxyrrhis marina and Acartia tonsa. (a) Chl a and (b) particulate organic $\mathrm{C}\left(\mathrm{PO}^{14} \mathrm{C}\right)$ based net loss coefficients $(g$ $-k$ ) in the 3 grazer treatments in the thin layers at high resolution (ca. $5 \mathrm{~cm}$ distance between valves). Bars: high $O$. marina $=$ mid-tone, $A$. tonsa $=$ light grey, low $O$. marina $=$ black. Loss coefficients were corrected for the losses observed in the Isochrysis galbana controls (see Fig. 8) ers, and that $O$. marina were grazing relatively more in the center and the bottom of the layers (Fig. 9). In the center valve and the lower thin layer valves, the loss coefficients in the $A$. tonsa treatment fell between the $2 O$. marina treatments as originally intended (Figs. 8 \& 9). Loss coefficients were consistently larger when using chl a than when using $\mathrm{PO}^{14} \mathrm{C}$ in the calculations (Fig. 9).

\section{Re-distribution of ${ }^{14} \mathrm{C}$}

Figs. $10 \& 11$ show the distribution of $\mathrm{DO}^{14} \mathrm{C}$ and $D{ }^{14} \mathrm{C}$, respectively, over time in the Oxyrrhis marina and Acartia tonsa treatments. Corrected for the Isochrysis galbana controls, a negative sign (bar to the left) indicates that there was less label in a particular fraction and treatment than in the matching control treatment (Figs. 10 \& 11). In the dinoflagellate grazer treatments, $\mathrm{PO}^{14} \mathrm{C}$ decreased in the thin layers due to grazing, but significantly increased in the lower part of the tank where $O$. marina migrated and resided (Table 2). Since $O$. marina cells were collected together with $I$. galbana, the $\mathrm{PO}^{14} \mathrm{C}$ values include contribution from both phytoplankton and grazer. However, this was not the case in the copepod treatments, since A. tonsa efficiently avoided being collected through the valve due to their strong negative rheotaxis and escape response. With respect to the organic fraction, in the O. marina treatment, $\mathrm{DO}^{14} \mathrm{C}$ was mainly and significantly redistributed downward, especially where grazer cells were present in high numbers (Fig. 10, Table 2). Substantial amounts of $\mathrm{DO}^{14} \mathrm{C}$ were also released into the thin layers, with smaller amounts of $\mathrm{DO}^{14} \mathrm{C}$ exported upwards due to fewer $O$. marina cells migrating in that direction (Fig. 10, Table 2). Overall the trend of $\mathrm{DO}^{14} \mathrm{C}$ relocation in $O$. marina treatments followed its distribution patterns observed in the cell counts (Fig. 5). In contrast, A. tonsa released almost no $\mathrm{DO}^{14} \mathrm{C}$ outside the layer, even in the upper part of the tank where it often resided. $\mathrm{DO}^{14} \mathrm{C}$ release was primarily in the lower part of the thin layer where grazing was high (Fig. 10). Table 2 summarizes the findings of multiple comparison tests among layers in each treatment. It shows that the $\mathrm{DO}^{14} \mathrm{C}$ release was significantly different among all treatments and for all valves, except at the valve in the center of the thin layer, which represented a 'switchover point' from one condition to the other (Table 2). In terms of $\mathrm{DI}^{14} \mathrm{C}$ release, the vertical distribution patterns mirrored those observed in the $\mathrm{DO}^{14} \mathrm{C}$ (Fig. 11, Table 2). However, the difference between the high $O$. marina treatments on the one hand and the low $O$. marina and $A$. tonsa treatments on the other was particularly striking below the thin 

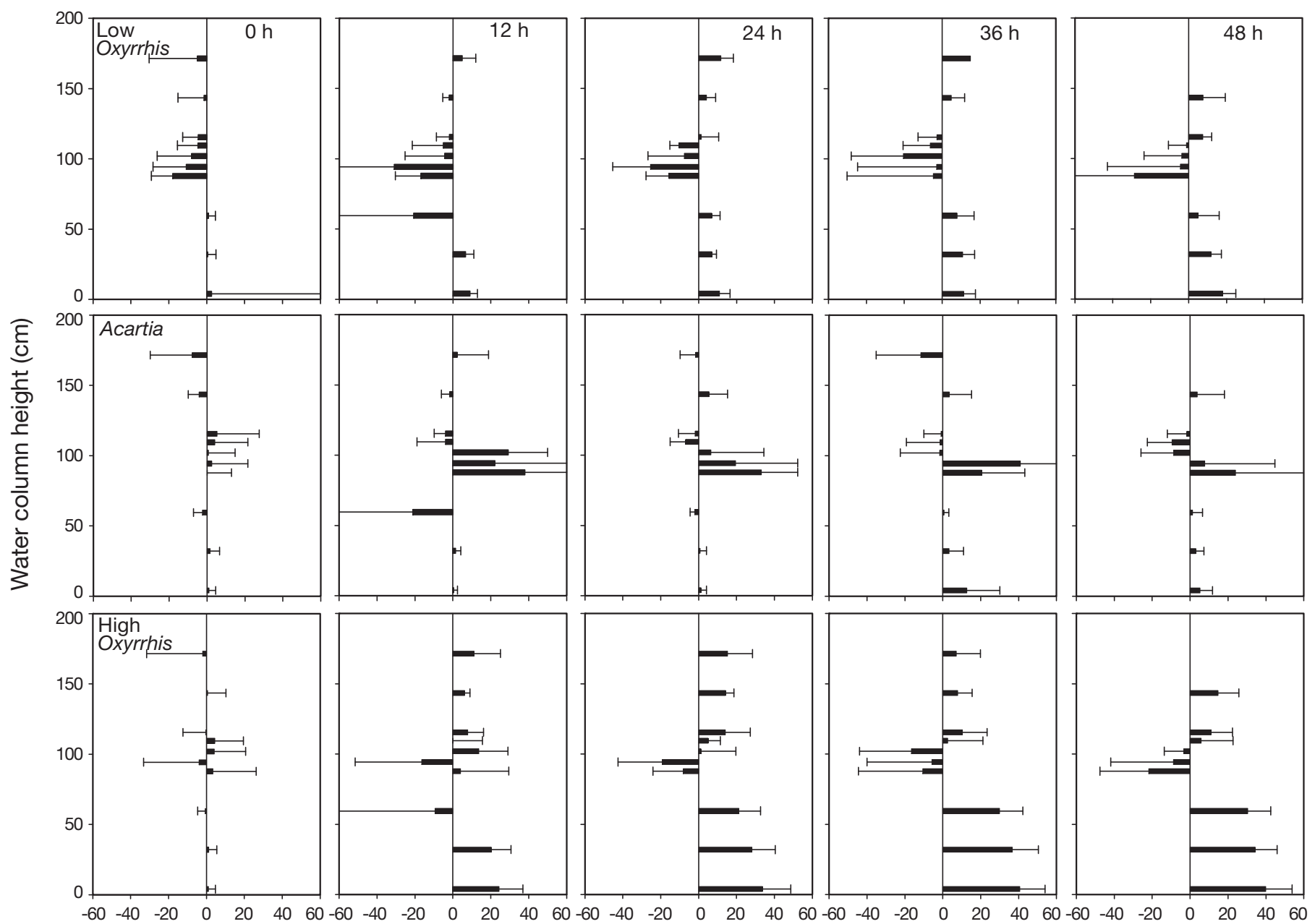

Net $\mathrm{DO}^{14} \mathrm{C}$ change (grazer treatments minus I. galbana control) (dpm)

Fig. 10. Oxyrrhis marina and Acartia tonsa. Net dissolved organic $\mathrm{C}\left(\mathrm{DO}{ }^{14} \mathrm{C}\right)$ distribution in the tanks over $48 \mathrm{~h}$ in $12 \mathrm{~h}$ intervals across all experiments, after subtracting values of $\mathrm{DO}^{14} \mathrm{C}$ in the Isochrysis galbana controls at each depth. Bars $=\mathrm{SD}$ of 5 independent experiments in different tanks. The 5 closely spaced valves in the center of the tank represent the location of the thin layers

layer, where $\mathrm{DI}^{14} \mathrm{C}$ release, and therefore respiration rate, was substantially greater in the high $O$. marina treatment than in the other 2 grazer treatments (Fig. 11, Table 2). The slopes of increases in net carbon in the 2 dissolved fractions over time are shown in Table 3 for the valves outside the thin layers (valve 1 and 2 above, and 8, 9 and 10 below the thin layers). These slopes thus represent net exports of carbon from the thin layers due to the grazers. In absolute values, O. marina exported more carbon in all dissolved fractions ( $\mathrm{TD}^{14} \mathrm{C}, \mathrm{DO}^{14} \mathrm{C}$ and $\mathrm{DI}^{14} \mathrm{C}$ ) than A. tonsa (Table 3). This was true for both $O$. marina treatments despite the fact that the low concentration of $O$. marina had a lower impact on the loss rates of I. galbana in the thin layer than A. tonsa.

\section{Release of ${ }^{14} \mathrm{C}$ to the atmosphere}

Ethanolamine samples were taken at the end of each experiment (48 h, Fig. 12a) and the next morning before the setup was dismantled (60 h, Fig. 12b) in order to give ${ }^{14} \mathrm{CO}_{2}$ sufficient time to diffuse out of the water column. Using a Tukey multiple pairwise comparison test in a general linear model using time as a covariate, the Acartia treatment had a significantly higher amount of ${ }^{14} \mathrm{CO}_{2}$ trapped than the other treatments (general linear model: ${ }^{14} \mathrm{C}_{\text {trap }}=\beta_{0}+\beta_{1} \times$ time + $\beta_{2} \times$ treatment $+\varepsilon$, where ${ }^{14} C_{\text {trap }}$ is the total amount of ${ }^{14} \mathrm{C}$ recovered in the traps in $\mathrm{dpm}$, and $\varepsilon$ the error term; $\mathrm{n}=24$, time: $F=4.60, \mathrm{p}=0.045$, treatment: $F=3.71, \mathrm{p}=$ 0.029). 


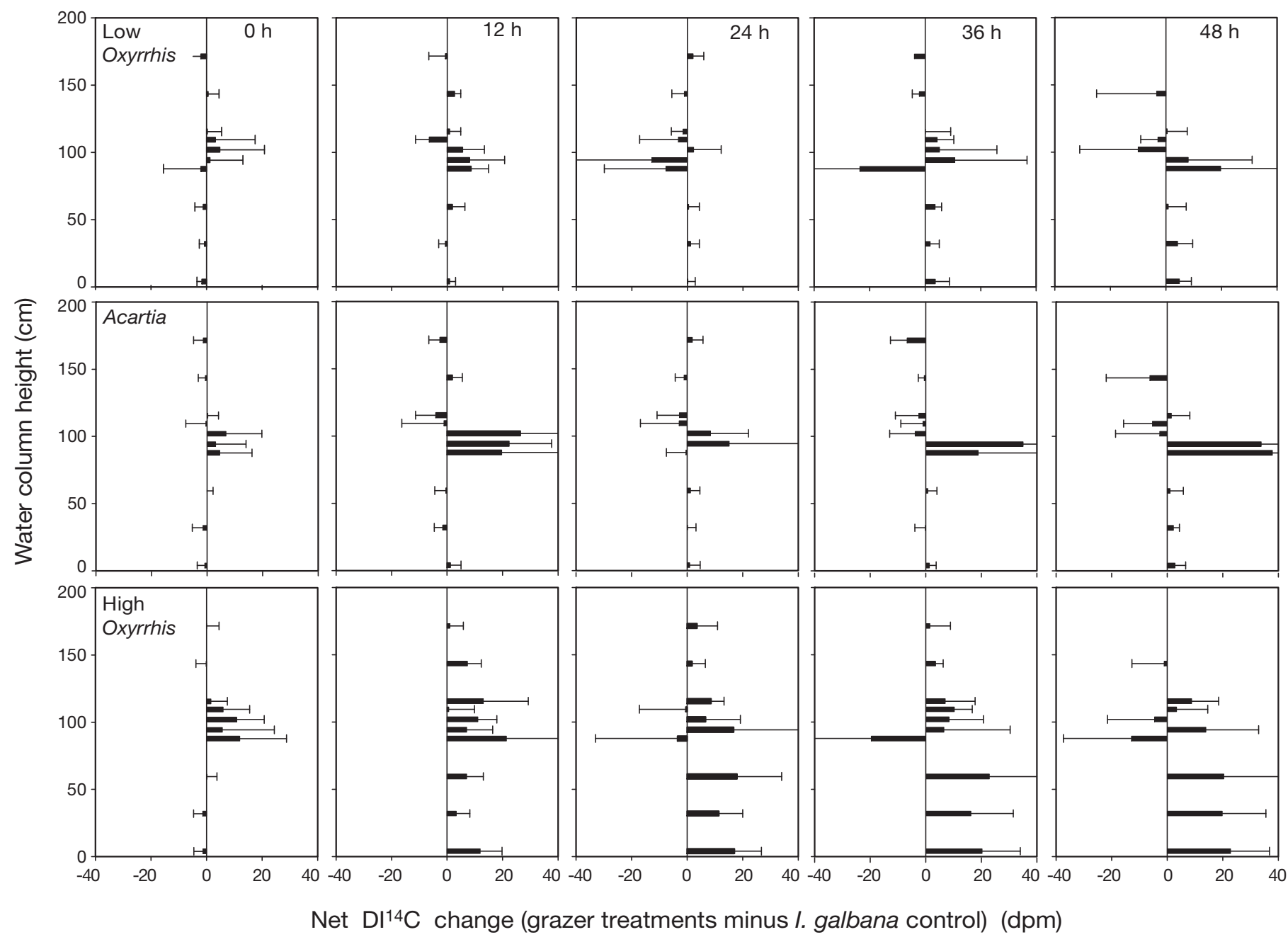

Fig. 11. Oxyrrhis marina and Acartia tonsa. Net dissolved inorganic $\mathrm{C}\left(\mathrm{DI}^{14} \mathrm{C}\right)$ distribution in the tanks over $48 \mathrm{~h}$ in $12 \mathrm{~h}$ intervals across all experiments, after subtracting values of $\mathrm{DI}^{14} \mathrm{C}$ in the Isochrysis galbana controls at each depth. Bars $=\mathrm{SD}$ of 5 independent experiments in different tanks. The 5 closely spaced valves in the center of the tank represent location of the thin layers

Table 2. Tukey's Studentized Range (HSD) Test for multiple comparisons of dissolved organic $\left(\mathrm{DO}^{14} \mathrm{C}\right)$ and inorganic $\left(\mathrm{DI}^{14} \mathrm{C}\right) \mathrm{car}-$ bon in the thin layer experiments. $1 \mathrm{Ox}=\mathrm{low}$ Oxyrrhis marina treatment; hOx = high O. marina treatment, Ac $=$ Acartia tonsa treatment. *Significant at the $\alpha=0.05$ level; $\mathrm{ns}=$ not significantly different. Output of the ANOVA table ( $\mathrm{n}, F$, and p-values) for overall effect of treatment is given for each row

\begin{tabular}{|c|c|c|c|c|c|c|c|c|}
\hline & Layer & Valves & $10 x-h O x$ & $1 O x-A c$ & $\mathrm{hOx}-\mathrm{Ac}$ & $\mathrm{n}$ & $F$ & $\mathrm{p}$ \\
\hline \multirow[t]{5}{*}{$\mathrm{DO}^{14} \mathrm{C}$} & Above thin layer & 1,2 & * & * & * & 110 & 35.93 & $<0.0001$ \\
\hline & Upper thin layer & 3,4 & $*$ & $*$ & * & 134 & 7.87 & $<0.0001$ \\
\hline & Middle thin layer & 5 & ns & $\mathrm{ns}$ & ns & 68 & 2.64 & 0.0572 \\
\hline & Lower thin layer & 6,7 & ${ }^{*}$ & $*$ & $*$ & 146 & 19.57 & $<0.0001$ \\
\hline & Below thin layer & $8,9,10$ & $*$ & * & * & 190 & 74.69 & $<0.0001$ \\
\hline \multirow{5}{*}{$\mathrm{DI}^{14} \mathrm{C}$} & Above thin layer & 1,2 & * & ns & * & 110 & 3.66 & 0.0148 \\
\hline & Upper thin layer & 3,4 & $*$ & ns & * & 134 & 5.66 & 0.0011 \\
\hline & Middle thin layer & 5 & $\mathrm{~ns}$ & $\mathrm{~ns}$ & $\mathrm{~ns}$ & 68 & 0.52 & 0.6705 \\
\hline & Lower thin layer & 6,7 & $\mathrm{~ns}$ & $\mathrm{~ns}$ & $\mathrm{~ns}$ & 146 & 2.69 & 0.0486 \\
\hline & Below thin layer & $8,9,10$ & * & * & * & 190 & 61.20 & $<0.0001$ \\
\hline
\end{tabular}




\section{Sinking fluxes from the thin layers}

The relative sinking fluxes due to fecal pellets released by Acartia tonsa were directly compared to the amount of passively sinking cells of Isochrysis galbana using samples taken from the bottom valves (i.e. the tip of the funnel, Fig. 1) over time. Since actively swimming Oxyrrhis marina cells were present to some extent in the bottom valves, we restrict our analysis to the comparison between I. galbana controls and the Acartia treatments. On average, sinking $\mathrm{PO}^{14} \mathrm{C}$ material amounted to $1685 \mathrm{dpm}$ over $48 \mathrm{~h}$ (sum of all bottom valve dpm in the I. galbana controls) over the 5 experiments. In the Acartia treatments, the total fluxes were $6500 \mathrm{dpm}$ or $\sim 4$ times the amount of passively sinking algal cells. Flux from the I. galbana layer remained constant over $48 \mathrm{~h}$ (linear regression slope: $\mathrm{n}=49, F=2.10, \mathrm{p}=0.15$ ). In contrast, it significantly increased over the same time interval in the Acartia treatment (linear regression slope: $\mathrm{n}=49, F=6.06, \mathrm{p}=0.0176$ ).

Table 3. Oxyrrhis marina and Acartia tonsa. Net export of total dissolved $\left(\mathrm{TD}^{14} \mathrm{C}\right)$, dissolved organic $\left(\mathrm{DO}^{14} \mathrm{C}\right)$ and dissolved inorganic $\left(\mathrm{DI}^{14} \mathrm{C}\right)$ carbon over time into regions above (valves 1,2) and below (valves 8, 9, 10) the thin layers. Columns from left to right $=$ increasing grazing pressure from low abundance of $O$. marina (low $\mathrm{Ox}$ ), to $A$. tonsa (Ac), to high abundance of $O$. marina (high $\mathrm{Ox}$ ). Linear regressions were fit to net $\mathrm{DO}^{14} \mathrm{C}$ and $\mathrm{DI}^{14} \mathrm{C}$ values for each valve over time and slope values calculated. In control treatments (Isochrysis galbana without grazers, not shown) there was no increase in ${ }^{14} \mathrm{C}$ in any of the dissolved fractions over time outside the layers (i.e. in valves 1, 2, 8, 9, 10 linear regressions slopes were not significant at $\alpha=0.05$ level and thus 0 ). All linear regression slopes in grazer treatments were significant at the $\alpha=0.05$ level except where 'ns' (not significant)

\begin{tabular}{|c|c|c|c|c|c|c|}
\hline \multirow[t]{2}{*}{ Valve } & \multicolumn{2}{|c|}{ 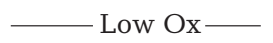 } & \multicolumn{2}{|l|}{$-\mathrm{Ac}-$} & \multicolumn{2}{|c|}{ - High Ox } \\
\hline & 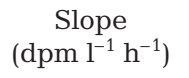 & $r^{2}$ & $\begin{array}{c}\text { Slope } \\
\left(\mathrm{dpm} \mathrm{l}^{-1} \mathrm{~h}^{-1}\right)\end{array}$ & $r^{2}$ & 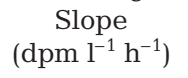 & $\mathrm{r}^{2}$ \\
\hline \multicolumn{7}{|l|}{$\mathrm{TD}^{14} \mathrm{C}$} \\
\hline 1 & 603 & 0.589 & 319 & 0.355 & 662 & 0.431 \\
\hline 2 & 413 & 0.549 & 331 & 0.538 & 480 & 0.541 \\
\hline 8 & 275 & 0.480 & 198 & 0.290 & 1227 & 0.399 \\
\hline 9 & 328 & 0.624 & 120 & 0.245 & 1149 & 0.552 \\
\hline 10 & 358 & 0.535 & 173 & 0.376 & 1272 & 0.516 \\
\hline \multicolumn{7}{|l|}{$\mathrm{DO}^{14} \mathrm{C}$} \\
\hline 1 & 252 & 0.330 & ns & - & 400 & 0.266 \\
\hline 2 & 266 & 0.433 & 235 & 0.260 & 307 & 0.624 \\
\hline 8 & 153 & 0.305 & ns & - & 692 & 0.568 \\
\hline 9 & 222 & 0.632 & ns & - & 688 & 0.601 \\
\hline 10 & 319 & 0.512 & 216 & 0.161 & 826 & 0.593 \\
\hline \multicolumn{7}{|l|}{$\mathrm{DI}^{14} \mathrm{C}$} \\
\hline 1 & 170 & 0.353 & 142 & 0.449 & 244 & 0.354 \\
\hline 2 & 146 & 0.224 & 94 & 0.197 & 162 & 0.213 \\
\hline 8 & 109 & 0.337 & 86 & 0.183 & 528 & 0.231 \\
\hline 9 & 091 & 0.250 & 59 & 0.266 & 448 & 0.398 \\
\hline 10 & 110 & 0.319 & ns & - & 447 & 0.387 \\
\hline
\end{tabular}

\section{DISCUSSION}

A common perception is that motile organisms move of layers more quickly than non-motile forms anality combined with taxis) is one of the strongest mechanisms for thin layer formation, far exceeding what can be expected by passive physical processes alone. When motile plankton organisms sense boundary conditions such as density gradients, they change their behavior in a fashion that leads to aggregations (Lougee et al. 2002, Bochdansky \& Bollens 2004). Alternatively, they may find a hard limit to their distribution in the water surface while swimming towards the light (e.g. Akashiwo sanguinea, Cullen \& Maclntyre 1998). In terms of thin layer stability, motile forms frity outperformed non-motile, passively sinking (this study) and Akashiwo sanguinea, both of which are very motile compared to Rhodomonas salina, for example, which settles very rapidly and is almost impossible to keep in a thin layer over many hours (A. B. Bochdansky unpubl. data). Many thin layers made of larger plankton are also driven by foraging activity, such as rotifers homing in on phytoplankton layers (Ignoffo et al. 2005).

We found the balance in the ratio of a thin layer organism and its predators that allowed us to simultaneously track the removal of $\mathrm{PO}^{14} \mathrm{C}$ from the thin layers, the release of $\mathrm{DI}^{14} \mathrm{C}$ and $\mathrm{DO}^{14} \mathrm{C}$ into the surrounding water column, and the release of ${ }^{14} \mathrm{CO}_{2}$ into the atmosphere above the tanks. The most striking result of our analysis was that grazing impact and release rates of dissolved carbon varied over very small $(<10 \mathrm{~cm})$ spatial scales. In addition, our results were consistent with the hypothesis that both types of grazers remained in contact with their food source throughout the entire experiment although the population maxima were located outside the layers. These kind of spatial relations between planktonic predators and prey are usually lost in bottle experiments, or in the field, where it is difficult to infer trophic relationships based on colocation of population maxima. We also succeeded in adding Oxyrrhis marina at densities that provided loss 


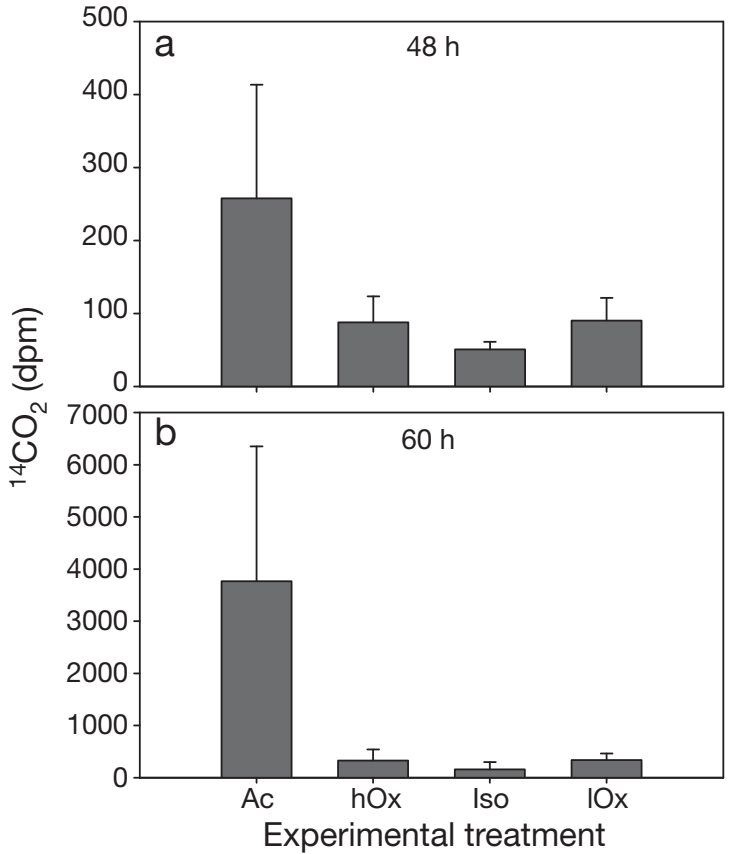

Fig. 12. Acartia tonsa, Isochrysis galbana and Oxyrrhis marina. Cumulative entrapment of ${ }^{14} \mathrm{CO}_{2}$ released into the atmosphere in all 4 treatments. $\mathrm{Ac}=A$. tonsa; Iso $=I$. galbana control; $10 \mathrm{x}=$ low and hOx $=$ high $O$. marina after (a) 48 and (b) $60 \mathrm{~h}$ of incubation

rates in the thin layers that fell above and below the ones of Acartia tonsa (Figs. 8 \& 9), and were therefore able to separate qualitative from quantitative effects of the 2 grazer types.

We observed differences in the vertical distribution over time of the 2 grazers. Most notably, Acartia tonsa consistently migrated into the upper half of the water column away from the thin layer, while Oxyrrhis marina moved into the lower half of the water column. However, both grazers seemed to return in large numbers to the thin layer to feed. There were 2 lines of evidence for this: First, despite the fact that most of the grazers left the layer, grazing losses continued at the same rate over the entire experiment, which would not have occurred if the population remaining in the layer was only a fraction of the total initial population. Second, these losses cannot be attributed to sinking cells because the layers of Isochrysis galbana were subtracted from the chlorophyll and $\mathrm{PO}^{14} \mathrm{C}$ values in the grazer treatments. $\mathrm{PO}^{14} \mathrm{C}$ without concomitant fluorescence signal in the Oxyrrhis treatments was a good indicator of the position of O. marina cells (Fig. 7). This was possible because chl a is rapidly digested into nonfluorescent products in O. marina (Barlow et al. 1988), while ${ }^{14} \mathrm{C}$ incorporated by the cells remained detectable in the $\mathrm{PO}^{14} \mathrm{C}$ fraction over longer time periods. Combined with some bacterial uptake of $\mathrm{DO}^{14} \mathrm{C}$ that contributed to the $\mathrm{PO}^{14} \mathrm{C}$ signal, this led to larger loss rates in terms of chl a than in terms of the $\mathrm{PO}^{14} \mathrm{C}$ fraction (Fig. 9). In all calculations involving ${ }^{14} \mathrm{C}$, there is the need to consider possible recycling of ${ }^{14} \mathrm{C}$ due to photosynthesis. Although it cannot be completely avoided, we minimized uptake using a low light environment that was sufficiently high to give $A$. tonsa light cues for migration. Light intensities at the depth of the thin layers were below $1 \mu \mathrm{mol} \mathrm{m} \mathrm{m}^{-2} \mathrm{~s}^{-1}$, close to the minimum required for photosynthesis for this species (Dubinsky et al. 1986). ${ }^{14} \mathrm{C}$ uptake by I. galbana was thus negligible.

In our experiments, the dinoflagellate Oxyrrhis marina generally moved away from the thin layer. In the field, population peaks of microzooplankton may or may not be collocated with thin layers. McManus et al. (2003) suggested that microzooplankton may avoid thin layers due to the production of toxins by thin layer phytoplankton. However, this does not explain why $O$. marina was not co-located with the Isochrysis galbana layers in our study. I. galbana is a very suitable food for this dinoflagellate; in fact we used I. galbana as the sole food source for $O$. marina cultures. Menden-Deuer \& Grünbaum (2006) studied in detail the behavioral repertoire of $O$. marina when encountering thin layers of I. galbana. They showed that frequency of turns and turn angles changed so that the predators accumulated in the thin layer for some time, but as in our experiments, O. marina dispersed after several hours of initially concentrating in the layer. However, the predominant trajectory of $O$. marina cells in the experiments of Menden-Deuer \& Grünbaum (2006) was upwards, while it was downward in our experiments. Not all microzooplankton move away from thin layers of phytoplankton as we observed here. Rotifers, for instance, initially aggregated and fed at the edges of thin layers of Nannochloropsis oculata, forming 2 distinct peaks immediately above and below the layers, perhaps seeking optimal prey concentrations for ingestion (Ignoffo et al. 2005). The rotifers subsequently dispersed only after the resource was depleted.

Similarly, copepods exploit thin layers for feeding but do not necessarily remain at the site of maximum prey abundances (Herman 1988, Napp et al. 1988, Bochdansky \& Bollens 2004, Sutor \& Dagg 2008). McManus et al. (2003) speculated that small copepods may stay away from thin phytoplankton layers in Monterey Bay because krill feed in these layers, and may also catch small copepods if present inside the layers. While it makes perfect sense that a predator will not conspicuously overlap with its prey for the sake of its own predator avoidance, these 'hit and run' grazers complicate interpretations of trophic interactions that are based on spatial distributions of predator and prey 
in the field. The scales of our $2 \mathrm{~m}$ tall tower tanks were thus ideal to study some of these small-scale predatorprey dynamics. They gave the grazers the opportunity to freely move in and out of the vicinity of their food source and allowed us to capture cm-scale features of grazing and carbon release patterns.

The relative grazing impact of mesozooplankton and microzooplankton on their prey varies widely depending on the system. While in general bottle incubations are considered the most reliable method of estimating feeding rates of plankton (Båmstaedt et al. 2000), there are many indications that the actual grazing impact may be underestimated in this manner (e.g. Nejstgaard et al. 2001). Another factor that may contribute to underestimating zooplankton grazing impacts may come from applying scales that are too coarse, as was demonstrated by Sutor \& Dagg (2008). As a percentage of standing crop of water-column integrated values, microzooplankton may graze 6 to $20 \%$ of phytoplankton (Landry \& Hassett 1982), while in other situations it may consume $41 \%$ (Capriulo \& Carpenter 1980). In terms of integrated primary production, the impact of microzooplankton can be very high, for instance $88 \%$ during the North Atlantic bloom experiment (Harrison et al. 1993) to even $100 \%$ in the Northern Adriatic Sea (Fonda-Umani et al. 2005). Grazing losses due to mesozooplankton are usually lower, also exhibiting wide ranges from as low as 0.4 to $1.98 \%$ of primary production (e.g. Lonsdale et al. 1996), but also reaching high percentages of standing stocks and primary production (50 to $76 \%$, respectively; e.g. Valiela 1984, FondaUmani et al. 2005).

These integrated values, however, do not tell us much about the fate of prey in some thin layers that may be the target of vertically migrating foragers. As we were able to demonstrate in previous experiments, total ingestion can be as high in a thin layer during short feeding bouts as when the same prey is distributed evenly throughout the water column (Bochdansky $\&$ Bollens 2004). This may be explained by the capacity of gorge feeding during short feeding bouts as seen in some copepods (McAllister 1971, Mackas \& Bohrer 1976). Moreover, repeated nighttime 'forays' into food patches have recently been confirmed in the field for Calanus pacificus and Metridia pacifica using traps in Dabob Bay, Washington (Pierson et al. 2009). In our experiments, we were able to demonstrate for the first time that feeding impact can be highly variable on $\mathrm{cm}$ scales even within the phytoplankton layer itself (Fig. 9). This small-scale resolution of the impact of grazing on thin layers can be expected in the field as well but is exceedingly difficult to measure. Thin layers are highly dynamic systems, some of which may only occur briefly before they are consumed or physically dispersed. Others may be more persistent because they can grow rapidly and utilize nutrients released by grazers. Persistence of layers may also be a reflection of the presence of less palatable prey or active grazing defenses (e.g. some cyanobacteria, or toxin-producing diatoms such as Pseudo-nitzschia, McManus et al. 2008).

Based on the release of $\mathrm{DI}^{14} \mathrm{C}$ and $\mathrm{DO}^{14} \mathrm{C}$ into the sites of the upper and lower portions of the tanks, we were able to calculate the amount of export of carbon for the 3 grazer treatments (slopes in Table 3). The Isochrysis galbana treatment (without grazers) provided the control to correct for 2 loss terms: sinking of cells (which was a small amount) and the respiration of already incorporated label by the algae. We thus arrive at an estimate of the export of carbon due to the grazers, and an estimate of the net release of organic and inorganic dissolved carbon. The type of grazer made a difference to the export of carbon out of the thin layers. Oxyrrhis marina exported more in terms of $\mathrm{DI}^{14} \mathrm{C}$ and $\mathrm{DO}^{14} \mathrm{C}$, even at lower grazing impact, than Acartia tonsa (Table 3). Despite the preference of $O$. marina to remain in the lower part of the tank and $A$. tonsa to move upwards, the export of $\mathrm{DI}^{14} \mathrm{C}$ and $\mathrm{DO}^{14} \mathrm{C}$ was larger in all directions in Oxyrrhis treatments. A. tonsa, in contrast, released most of the $\mathrm{DI}^{14} \mathrm{C}$ and $\mathrm{DO}^{14} \mathrm{C}$ into the thin layer (Figs. $10 \& 11$ ) and into the atmosphere (Fig. 12). Regarding the release into air, it is important to consider the relative scales: the absolute amount of label that accumulated in the atmosphere over time was only $0.01 \%$ of the label ingested in the thin layer. Over time, and with more label moving in the upper part of the tank, the relative contribution of ${ }^{14} \mathrm{C}$ in carbon dioxide would have increased non-linearly because of an increasing body burden of ${ }^{14} \mathrm{C}$ with time, and consistent with the higher values observed after $60 \mathrm{~h}$ (Fig. 12). While it is interesting that we obtained a stronger atmospheric ${ }^{14} \mathrm{CO}_{2}$ signal in the Acartia treatment in comparison to the Oxyrrhis treatment, this may be partly due to their distribution in the upper water column.

Our estimates of the release of DOC represent minima because of the presence of bacteria which take up organic material and are largely retained by the GF/F filters (i.e. are part of the $\mathrm{PO}^{14} \mathrm{C}$ ). According to Strom et al. (1997), an average of ca. $40 \%$ of the dissolved organic matter (DOM) released by grazing of Oxyrrhis marina was taken up by heterotrophic bacteria at the same time scale at which we performed our experiments (48 h). As in Strom et al. (1997), bacteria increased in numbers in all of our treatments, especially in the thin layers and in the upper water column.

In comparison to the amount of particulate material removed by grazing and incorporated into body tissue, overall very little was lost as DIC and DOC. However, the relatively larger DOC export from the layer in the 
dinoflagellate treatment was most likely due to the fact that protists release digested material that becomes part of the colloidal and dissolved matter pool (Caron et al. 1985, Taylor et al. 1985, Isao et al. 1990, Nagata \& Kirchman 1997). Copepods on the other hand produce larger, fast-sinking fecal pellets that would show up in the particulate fraction only for a short period of time before sinking to the bottom of the tank. One can make the assumption that 25 to $30 \%$ of the carbon removed from the layer would end up unassimilated and packed into fecal pellets in the Acartia treatment (Conover 1966, Bochdansky et al. 1999).

The increase of DIC inside the layer in the Acartia treatment (Fig. 11) could be due to an increased respiration rate while feeding, including specific dynamic action. If the observed DIC release were a reflection of increased feeding activity, it would contradict hydrodynamic models that suggest that very little energy is expended due to the mechanical action of feeding (van Duren et al. 2003). Another source of DIC is bacteria that take up freshly released DOC and then respire. While released DIC simply becomes part of the carbonate system, the quality of the released DOM and its stoichiometric composition likely differs among treatments, because in one case it represents surplus sugars (excreted from the algae), in another digested material (release of food vacuoles in protists), and in another, undigested cell contents (due to copepod sloppy feeding). Differential pathways of utilization warrant future studies on the biochemistry and bioavailability of these released materials.

Much DOC was released inside the thin layer in all treatments, including the Isochrysis galbana controls; however, the amount of DIC and DOC released inside the layer was greatest in the Acartia treatment. The increased release of DOC in the layer was likely a result of sloppy feeding (Conover 1966, Dagg 1974, Lampert 1978, Roy et al. 1989), but DOC release was also observed in zooplankton that ingest whole organisms (Urban-Rich et al. 2006, Condon et al. 2008). These authors showed that there was always some loss of DOC due to grazing, but the loss was comparably smaller when the copepods ingested small cells (Møller 2007). There is a discrepancy between the trend observed in Møller (2007) and our data. According to Møller (2007), significant release of DOM due to sloppy feeding occurred only in situations in which predators were not more than 39 times larger in linear dimension than their prey. The ratio between Acartia tonsa and $I$. galbana in our experiments was closer to 100, yet DOM release was clearly detectable. One solution to this discrepancy is different incubation periods (i.e. 20 to $30 \mathrm{~min}$ in Møller 2007 and $48 \mathrm{~h}$ in our experiments). It is therefore reasonable to assume that the DOM released into the thin layers in our experi- ment was not solely due to sloppy feeding but a result of diffusion of DOC through the peritrophic membrane of fecal material (Jumars et al. 1989) as well as possible excretion and accumulation of some primary amines (Miller \& Glibert 1998). It may also derive from small particulate material that is egested by copepods but not bound by a peritrophic membrane (Olesen et al. 2005), and through coprohexy (Lampitt et al. 1990). The notion of high fecal pellet production at the site of feeding is supported by experimental studies that show fecal production rate is highly synchronous with grazing activity (measured by gut fluorescence, Bautista et al. 1988). If we had used larger phytoplankton cells, the release of DOM may have been even larger than what we observed here (Møller \& Nielsen 2001, Møller 2007).

An important result of our high resolution analysis was the difference between the dynamics of DOC in the upper and the lower part of the thin layers among treatments (Fig. 10, Table 2). One may expect that there is always a net release of DOC or DIC because of the presence of the grazers, but this was not what we observed. Acartia tonsa, which spent most of its time in the upper water column, had the largest grazing impact in the top part of the thin layer (Fig. 9, Table 2). On the other hand, Oxyrrhis marina was most abundant in the lower part of the tanks and grazed most heavily on the bottom half of the thin layer, and thus released much of the DOC and DIC there (Figs. 5, 10 \& 11). Here we demonstrate that the net release of DOC in the thin layers was inversely related to the intensity of grazing on the phytoplankton population. This initially counterintuitive result was consistent across treatments, the 2 types of grazers, and over time (Figs. $7 \& 10$ ). Where grazers most heavily impacted the phytoplankton population (i.e. A. tonsa in the upper thin layer and $O$. marina in the bottom thin layer), the net effect on DOC and DIC release was negative because of the removal of phytoplankton, which themselves released dissolved carbon. When the grazing impact was moderate, DOC could accumulate because of the combined effect of sloppy feeding, defecation and the release from remaining phytoplankton cells. Valve 5, in the center of the thin layer, represented a transition zone between positive and negative effects on DOC release (in both directions for both treatments), leading to values that were not significantly different among treatments there (Table 2).

We thus arrive at a conceptual relationship between grazing pressure and the net release of DOM from phytoplankton cells (Fig. 13). At low grazing activity, most DOC release is due to algal exudation. At intermediate grazing, DOC release is maximized by the combined effect of grazer and algal DOC releases. Above a certain grazing threshold, the net release of 


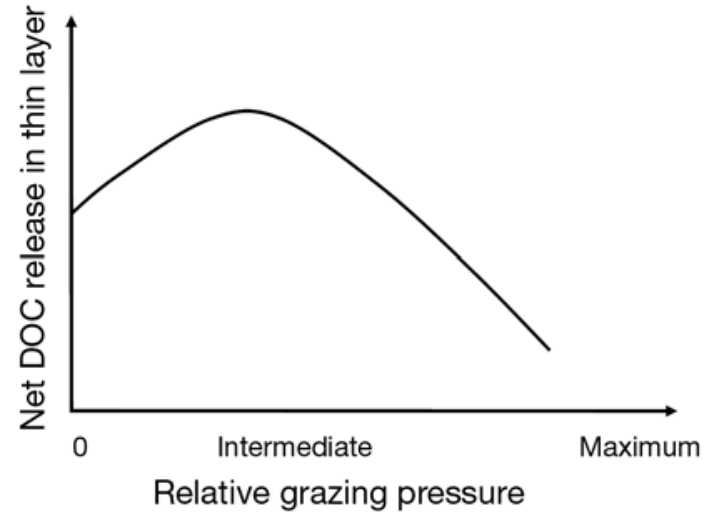

Fig. 13. Conceptual diagram of how varying grazing pressures on thin layers may affect the net release of dissolved organic $\mathrm{C}$ (DOC). At low grazing rates, there is a net contribution of grazers to the DOC pool. At high grazing rates, less $\mathrm{DOC}$ is released due to the removal of primary producers (i.e. net DOC releasers)

DOC is negative (i.e. below that of the phytoplankton control) because most of the carbon is incorporated into the body tissue of the grazer (Fig. 13). It has been hypothesized that grazers may leave DOM signatures behind if the grazing pressure on a population of phytoplankton is high (Urban-Rich et al. 2006). One of the most desirable characteristics of such proposed grazing-related signatures is that they stay in place while grazers move quickly in and out of their prey fields. They may thus be used as indicators of actual grazing activity and compared to actual patterns of predator-prey distributions. However, there are several problems in finding grazer-mediated DOM signatures in the field, of which the most obvious is the rapid removal and utilization of DOM by bacteria. Our study suggests a second, usually less considered problem: during high grazing activity, zooplankton may reduce net DOM production (and thereby the background of DOM) because the grazers remove other producers of DOM (i.e. phytoplankton; Twardowski \& Donaghay 2001). Grazers therefore have a direct effect on DOM release due to cell breakage and the release of food vacuole content, and an indirect effect due to the impact on phytoplankton densities. Our findings therefore further complicate the prospect of finding a muchdesired relationship between DOM signatures and grazing activity in the field.

\section{CONCLUSIONS}

We resolved differences in trophodynamic processes between meso- and microzooplankton grazers in and around thin layers at small spatial scales. Copepods and protists removed significant amounts of phyto- plankton biomass from the thin layers and released DOC and DIC inside and outside the layers in the process. The extent to which these processes (grazing and release) occurred was dependent on the type of grazers, with the protist exporting dissolved carbon considerably more than the copepod. The copepod, on the other hand, released more dissolved organic and inorganic carbon back into the layer. The magnitude of these carbon releases into the dissolved fraction was small in comparison to the movement of carbon in the particulate fraction (e.g. as body burden). This leaves a large quantity of carbon available for higher trophic levels, and only to a lesser degree fuels the microbial loop in and outside the thin layers. Due to their migration in the upper part of the water column, the copepods also moved carbon from the thin layer to the surface of the water, which then escaped as $\mathrm{CO}_{2}$ into the atmosphere. The carbon budgets of removal and addition of the 3 fractions of carbon (POC, DIC and DOC) can vary significantly at very small spatial scales, even within a $30 \mathrm{~cm}$ thin layer. An important consideration in such budgets is the removal of 'releasers' of DOC and DIC (i.e. the primary producers themselves). Using DOC release as a signature for grazing activity in the natural environment is therefore extremely challenging, and may only be feasible if more specific substances can be identified as tracers.

Acknowledgements. We thank S. Sylvester for graciously providing laboratory space and instruments used for radioisotope analyses; M. Lummio and J. Breckenridge for assistance during culturing and tower tank experiments; L. Friedenberg for cell counting; and R. Hooff for assistance with copepod cultures. We also thank S. Strom at the Shannon Point Marine Center (Anacortes, Washington) for providing the Oxyrrhis marina cultures. This project was supported by grants from the Office of Naval Research \#N000140610200 to S.M.B. \& G.C.R.-B., and \# N000140610201 to A.B.B.

\section{LITERATURE CITED}

Abbott CK, Sorensen DL, Sims RC (1992) Use and efficiency of ethylene-glycol monomethyl ether and monoethanolamine to trap volatilized [7-C-14]Napthalene and (CO2)-C-14. Environ Toxicol Chem 11:181-185

Alldredge AL, Cowles TJ, MacIntyre S, Rines JEB and others (2002) Occurrence and mechanisms of formation of a dramatic thin layer of marine snow in a shallow Pacific fjord. Mar Ecol Prog Ser 233:1-12

Båmstaedt U, Gifford DJ, Irigoien DJ (2000) Feeding. In: Harris R, Wiebe P, Lenz J, Skoldal HR, Huntley M (eds) ICES zooplankton methodology manual. Academic Press, London

Barlow RG, Burkill PH, Mantoura RFC (1988) Grazing and degradation of algal pigments by marine protozoan Oxyrrhis marina. J Exp Mar Biol Ecol 119:119-129

Bautista B, Rodriguez V, Jimenez F (1988) Short-term feeding rates of Acartia grani in natural conditions: diurnal variation. J Plankton Res 10:907-920 
Bochdansky AB, Bollens SM (2004) Relevant scales in zooplankton ecology: distribution, feeding, and reproduction of the copepod Acartia hudsonica in response to thin layers of the diatom skeletonema costatum. Limnol Oceanogr 49:625-636

Bochdansky AB, Bollens SM (2009) Thin layer formation during runaway stratification in the tidally dynamic San Francisco Estuary. J Plankton Res 31:1385-1390

Bochdansky AB, Deibel D, Rivkin RB (1999) Absorption efficiencies and biochemical fractionation of assimilated compounds in the cold water appendicularian Oikopleura vanhoeffeni. Limnol Oceanogr 44:415-424

Capriulo GM, Carpenter EJ (1980) Grazing by 35 to $202 \mu \mathrm{m}$ microzooplankton in Long Island Sound. Mar Biol 56: 319-326

> Caron DA, Goldman JC, Andersen OK, Dennett MR (1985) Nutrient cycling in a microflagellate food chain: II. Population dynamics and carbon cycling. Mar Ecol Prog Ser 24:243-254

Clay TW, Bollens SM, Bochdansky AB, Ignoffo TR (2004) The effects of thin layers on the vertical distribution of larval pacific herring, Clupea pallasi. J Exp Mar Biol Ecol 305: 171-189

Condon RH, Steinberg DK, Bronk DA (2010) Production of dissolved organi matter and inorganic nutrients by gelatinous zooplankton in the York River estuary, Chesapeake Bay. J Plankton Res 32:153-170

Conover RJ (1966) Factors affecting the assimilation of organic matter by zooplankton and the question of superfluous feeding. Limnol Oceanogr 11:346-354

Conover RJ, Francis V (1973) The use of radioactive isotopes to measure the transfer of materials in aquatic food chains. Mar Biol 18:272-283

Cowles TJ, Desiderio A, Carr MC (1998) Small-scale planktonic structure: persistence and trophic consequences. Oceanography 11:4-9

Cullen JJ, MacIntyre JG (1998) Behavior, physiology and the niche of depth-regulating phytoplankton. In: Anderson DM, Cembella AD, Hallegraeff GM (eds) Physiological ecology of harmful algal blooms. Springer, Berlin

Dagg MJ (1974) Loss of prey body contents during feeding by an aquatic predator. Ecology 55:903-906

Dekshenieks MM, Donaghay PL, Sullivan JM, Rines JEB, Osborn TR, Twardowski MS (2001) Temporal and spatial occurrence of thin phytoplankton layers in relation to physical processes. Mar Ecol Prog Ser 223:61-71

Dubinsky Z, Falkowski PG, Wyman K (1986) Light harvesting and utilization by phytoplankton. Plant Cell Physiol 27: 1335-1349

Fonda Umani S, Tirelli V, Beran A, Guardiani B (2005) Relationships between microzooplankton and mesozooplankton: competition versus predation on natural assemblages of the Gulf of Trieste (northern Adriatic Sea). J Plankton Res 27:973-986

Frost BW (1972) Effects of size and concentration of food particles on the feeding behavior of the marine planktonic copepod Calanus pacificus. Limnol Oceanogr 17:805-815

Guillard RLL (1983) Culture of phytoplankton for feeding invertebrate animals. In Berg CJ (ed) Culture of marine invertebrates. Hutchinson Ross, Stroudsberg, PA, p 108-132

> Hansen FC, Witte HJ, Passarge J (1996) Grazing in the heterotrophic dinoflagellate Oxyrrhis marina: size selectivity and preference for calcified Emiliania huxleyi cells. Aquat Microb Ecol 10:307-313

Harrison WG, Head EJH, Horne EPW, Irwin B and others (1993) The western North Atlantic bloom experiment (NABE). Deep-Sea Res 40:279-305
Herman AW (1988) Simultaneous measurement of zooplankton and light attenuance with a new optical plankton counter. Cont Shelf Res 8:205-221

Ignoffo TR, Bollens SM, Bochdansky AB (2005) The effects of thin layers on the vertical distribution of the rotifer, Brachionus plicatilis. J Exp Mar Biol Ecol 316:167-181

> Isao, K, Hara S, Terauchi K, Kogure K (1990) Role of submicrometre particles in the ocean. Nature 345:242-244

Jumars PA, Penry DL, Baross JA, Perry MJ, Frost BW (1989) Closing the microbial loop: dissolved carbon pathway to heterotrophic bacteria from incomplete ingestion, digestion, and absorption in animals. Deep-Sea Res 36:483-495

Kiørboe T (1989) Phytoplankton growth rate and nitrogen content: implications for feeding and fecundity in a herbivorous copepod. Mar Ecol Prog Ser 55:229-234

Kuparinen J, Uusi-Rauva A (1980) A simplified technique to measure respiration rates of aerobic heterotrophic populations. Hydrobiologia 75:113-115

Lampert W (1978) Release of dissolved organic carbon by grazing zooplankton. Limnol Oceanogr 23:831-834

> Lampitt RS, Noji T, von Bodungen B (1990) What happens to zooplankton faecal pellets? Implications for material flux. Mar Biol 104:15-23

Landry MR, Hassett RP (1982) Estimating the grazing impact of marine microzooplankton. Mar Biol 67:283-288

Lonsdale DJ, Cosper EM, Doall M (1996) Effects of zooplankton grazing on phytoplankton size-structure and biomass in the lower Hudson River Estuary. Estuaries 19:874-889

> Lougee LA, Bollens SM, Avent SR (2002) The effects of haloclines in the vertical distribution and migration of zooplankton. J Exp Mar Biol Ecol 278:111-134

> Mackas D, Bohrer R (1976) Fluorescence analysis of zooplankton gut contents and an investigation of diel feeding patterns. J Exp Mar Biol Ecol 25:77-85

McAllister CD (1971) Some aspects of nocturnal and continuous grazing by herbivores in relation to production studies. Fish Res Board Can Tech Rep 248:281

McManus MA, Alldredge AL, Barnard AH, Boss E and others (2003) Characteristics, distribution and persistence of thin layers over a 48 hour period. Mar Ecol Prog Ser 261:1-19

> McManus MA, Kudel RM, Silver MW, Steward GF, Donaghay PL, Sullivan JM (2008) Cryptic blooms: Are thin layers the missing connection? Estuaries Coasts 31:396-401

Menden-Deuer S, Grünbaum D (2006) Individual foraging behaviors and population distributions of a planktonic predator aggregating to phytoplankton thin layers. Limnol Oceanogr 51:109-116

> Miller CA, Glibert PM (1998) Nitrogen excretion by the calanoid copepod Acartia tonsa: results of mesocosm experiments. J Plankton Res 20:1767-1780

Møller EF (2007) Production of dissolved organic carbon by sloppy feeding in the copepods Acartia tonsa, Centropages typicus, and Temora longicornis. Limnol Oceanogr 52:79-84

> Møller EF, Nielsen TG (2001) Production of bacterial substrate by marine copepods: effect of phytoplankton biomass and cell size. J Plankton Res 23:527-536

Nagata T, Kirchman DL (1997) Roles of submicron particles and colloids in microbial food webs and biogeochemical cycles within marine environments. Adv Microb Ecol 15: 81-103

Napp JM, Brooks ER, Reid FMH, Matrai P, Mullin MM (1988) Vertical distribution of marine particles and grazers. I. Vertical distribution of food quality and quantity. Mar Ecol Prog Ser 50:45-58

Nejstgaard JC, Naustvoll LJ, Sazhin A (2001) Correcting for underestimation of microzooplankton grazing in bottle 
incubation experiments with mesozooplankton. Mar Ecol Prog Ser 221:59-75

Nielsen MV, Olsen Y (1989) The dependence of the assimilation efficiency in Daphnia magna on the super(14)C-labeling period of the food alga Scenedesmus acutus. Limnol Oceanogr 34:1311-1315

Olesen M, Strake S, Andrushaitis A (2005) Egestion of nonpellet-bound fecal material from the copepod Acartia tonsa: implication for vertical flux and degradation. Mar Ecol Prog Ser 293:131-142

Pierson JJ, Frost BW, Thoreson D, Leising AW, Postel JR, Nuwer M (2009) Trapping migrating zooplankton. Limnol Oceanogr Methods 7:334-346

Porter KG, Feig YS (1980) The use of DAPI for identifying and counting aquatic microflora. Limnol Oceanogr 25: 943-948

Rines JEB, Donaghay PL, Dekshenieks MM, Sullivan JM, Twardowski MS (2002) Thin layers and camouflage: hidden Pseudo-nitzschia spp. (Bacillariophyceae) populations in a fjord in the San Juan Islands, Washington, USA. Mar Ecol Prog Ser 225:123-137

Roy S, Harris RP, Poulet SA (1989) Inefficient feeding by Calanus helgolandicus and Temora longicornis on Coscinodiscus wailesii: quantitative estimation using chlorophyll-type pigments and effect on dissolved free amino acids. Mar Ecol Prog Ser 52:145-153

Ryan JP, McManus MA, Paduan JD, Chavez FP (2008) Phytoplankton thin layers caused by shear in frontal zones of a coastal upwelling system. Mar Ecol Prog Ser 354: 21-34

Editorial responsibility: Peter Verity,

Savannah, Georgia, USA
Stacey MT, McManus MA, Steinbuck JV (2007) Convergences and divergences and thin layer formation and maintenance. Limnol Oceanogr 52:1523-1532

Strickland JD, Parsons TR (1972) A practical handbook of seawater analysis, 2nd edn. Bull Fish Res Board Can 167

Strom SL, Benner R, Ziegler S, Dagg MJ (1997) Planktonic grazers are a potentially important source of marine dissolved organic carbon. Limnol Oceanogr 42:1364-1374

Sutor MM, Dagg MJ (2008) The effects of vertical sampling resolution on estimates of plankton biomass and rate calculations in stratified water columns. Estuar Coast Shelf Sci 78:107-121

> Tang KW, Taal M (2005) Trophic modification of food quality by heterotrophic protists: species-specific effects on copepod egg production and egg hatching. J Exp Mar Biol Ecol 318:85-98

Taylor GT, Iturriaga R, Sullivan CW (1985) Interactions of bactivorous grazers and heterotrophic bacteria with dissolved organic matter. Mar Ecol Prog Ser 23:129-141

Twardowski, Donaghay PL (2001) Separating in situ and terrigenous sources of absorption by dissolved materials in coastal oceans. J Geophys Res 106(C2):2545-2560

> Urban-Rich J, McCarty JT, Fernandez D, Acuna JL (2006) Larvaceans and copepods excrete fluorescent dissolved organic matter (FDOM). J Exp Mar Biol Ecol 332:96-105

Valiela I (1984) Marine ecological processes. Springer, New York

van Duren LA, Stamhuis EJ, Videler JJ (2003) Copepod currents: flow patterns, filtration rates and energetics. J Exp Biol 206:255-267

Submitted: February 9, 2009; Accepted: November 18, 2009 Proofs received from author(s): February 24, 2010 